\title{
Pawns of the State or Priests of Democracy? Analyzing Professors' Academic Freedom Rights Within the State's Managerial Realm
}

\author{
Rebecca Gose Lynch $\dagger$
}

\section{TABLE OF CONTENTS}

Introduction.

I. Background to Understanding the Concept of Academic Freedom 1066

A. The Development of "Professional" Academic Freedom:

Professional Ethics Regarding Self-Government and

Professorial Autonomy

B. The Development of "Constitutional" Academic Freedom:

The Supreme Court's Dedication to Academic Freedom as

a First Amendment Right.

C. The Quagmire: Conflicting Approaches to Academic

Freedom

II. A Functional Necessity Approach to Academic Freedom Within the State's Managerial Domain

A. Setting up the Framework: Public Employees' Rights in the State's Managerial Domain.

Copyright $(2003$ California Law Review, Inc. California Law Review, Inc. (CLR) is a California nonprofit corporation. CLR and the authors are solely responsible for the content of their publications.

$\dagger$ Law Clerk, The Honorable David M. Ebel, United States Court of Appeals for the Tenth Circuit; J.D., School of Law, University of California, Berkeley (Boalt Hall), 2003; B.A., University of Colorado, Boulder, 1997. I would like to thank Professor Robert C. Post for his insightful guidance throughout the writing of this Comment, as well as for his fascinating instruction in First Amendment law. Great thanks are also due to the following professors, who provided helpful comments on earlier drafts: Richard H. Fallon, Kenneth L. Karst, and Jack M. Graves, who was one of my early supporters and who continues to be a source of encouragement. I am also particularly grateful for help rendered by Jeffrey L. Bleich, who always found the time to provide guidance not only in writing this Comment but in all school and career matters. I acknowledge and appreciate the editorial assistance of the staff at the California Law Review, especially Sarah Abbott, Susan Brehm, Chris Hazuka, Matt McDermott, Karen Petroski, Sarah Shaw, and David Steiner. Any errors are my own. Finally, loving thanks to my husband and best friend, Damian, for supporting me through law school and life, and to my parents, Mark and Eileen, and my brother, Nathaniel, all of whom taught me to crave learning and laughter. 
1. Step One: The Threshold Characterization of the State as Either Governor or Manager-Determining Whether the State Has an Interest in a State Employee's Speech..... 1074

2. Step Two: The Operative Question-Determining Whether the Regulation of a State Employee's Speech Is Functionally Necessary to Accomplish the State's Legitimate Managerial Goals

3. When Judicial Deference to the State's Managerial Judgment Is Warranted.

4. Summary 1080

B. Applying the Functional Necessity Approach to Academic Freedom

1. Determining When Professors Speak Within the State's Managerial Domain 1081

2. Determining the Operative Question of Functional Necessity in the Academic Arena 1082

a. Goals of the University ............................................. 1083

b. Role of the Professor...................................................... 1084

3. Defining Constitutional Academic Freedom: First Amendment Rights in an Institutional Context. 1090

4. Benefits of the Functional Necessity Approach to Academic Freedom 1093

III. Where Urofsky Went Wrong I099

A. The Urofsky Court's Failure to Investigate the Operative Question of Functional Necessity 1099

B. The Urofsky Court's Distinction Between Institutional and Individual Academic Freedom. 


\title{
Pawns of the State or Priests of Democracy? Analyzing Professors' Academic Freedom Rights Within the State's Managerial Realm
}

\author{
Rebecca Gose Lynch
}

The image of public university professors shackled as pawns of the state is repugnant to the American concept of a democratic free society. Without protection for academic freedom, however, such an image could represent the future role of professors at public universities. The law in this area has been in disarray for years, and although the Supreme Court has extolled the virtues of First Amendment academic freedom rights for both professors and universities, it has provided no explicit mechanism for deciding these cases. Confusion among lower courts and commentators as to the nature of these rights recently culminated in the Fourth Circuit's categorical denial of constitutional academic freedom to professors in Urofsky v. Gilmore. The clearly incorrect result in Urofsky makes more imperative than ever careful clarification of the proper approach to cases involving claims of constitutional academic freedom.

This Comment argues that the confusion is unnecessary because, although the Court has not given explicit guidance, its public employee jurisprudence provides all of the tools lower courts need to decide these important cases. Because academic speech is made by public employees within public institutions and is thus subject to the state's managerial power, this Comment advocates applying a reformulated public employee framework. Specifically, courts should utilize a functional necessity test when deciding public university professors' academic freedom claims. This Comment analyzes already decided cases against this backdrop, demonstrating that although courts purport to be operating under different frameworks, similar analysis goes on behind the scenes: courts protect professorial academic freedom rights when restriction of academic expression is not functionally necessary to the state's legitimate goals. In fact, where the state's goals are critical democratic education or the promotion of new discoveries, academic freedom is not a hindrance but rather is crucial to the accomplishment of the state's mission. 
Approaching constitutional academic freedom in this way eliminates the need to distinguish between individual and institutional rights in situations like those presented in Urofsky, and demonstrates that the Urofsky court should not have categorically denied such freedom to professors. Unlike the Urofsky court's analysis of academic freedom rights, the framework outlined in this Comment is specifically motivated by the values the Supreme Court has advanced in its discussions of both academic freedom and public employee speech rights and protects more expression than alternative approaches do.

\section{INTRODUCTION}

"Our progress as a Nation can be no swifter than our progress in education." With this statement, President John F. Kennedy illustrated the dependence of democracy upon educational institutions. This connection between democracy and education also appears in the linkage between political freedom and academic freedom. Supreme Court Justices have emphasized the dependencc of a free society on unfettered universities, ${ }^{2}$ depicting professors as the "priests of our democracy." Indeed, the Court has proclaimed that " $[t]$ he essentiality of freedom in the community of American universities is almost self-evident."4 Less self-evident, however, are the legal means for protecting academic freedom, as well as the scope of the right. The lack of clarity in this area of the law became apparent when the Fourth Circuit issued its staggering declaration in Urofsky $v$.

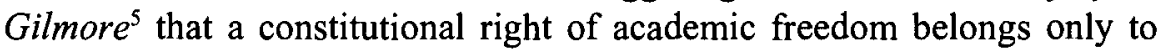
public universities, not to individual professors within those universities. In so doing, the court essentially relegated public university professors to being pawns of the state. ${ }^{6}$

Presently, courts and commentators have not developed a clear doctrinal basis for analyzing academic freedom cases. Although the Supreme Court has expressed much eloquent respect for the freedom of professors and universities, it has set forth no explicit standard or mechanism for analysis in cases implicating this value. Consequently, lower courts that have faced a professor's or university's assertion of a "right" of academic freedom have produced a quagmire of conflicting standards. Here, I seek to sort through the confusion and provide a workable standard for approaching academic freedom cases.

1. President's Special Message to Congress on Education, H.R. Doc. No. 92, at 2429 (Feb. 20, 1961).

2. See Sweezy v. New Hampshire, 354 U.S. 234, 262 (1957) (Frankfurter, J., concurring).

3. Wieman v. Updegraff, 344 U.S. 183, 196 (1952) (Frankfurter, J., concurring).

4. Sweezy, 354 U.S. at 250.

5. 216 F.3d 401, 412 (4th Cir. 2000).

6. Throughout this Comment, 1 use the term "state" as a gencric label for "government," whether it be at the fcderal or state level. 
This Comment proceeds in three parts. Part I provides a background of the concept of academic freedom. It explains that the label is used to refer to two different notions. "Professional" academic freedom, as set forth by the American Association of University Professors ("AAUP"), is a canon of self-imposed professional ethics applying to both public and private universities. In contrast, "constitutional" academic freedom, as set forth in various cases relying on the First Amendment, limits state action. Although constitutional academic freedom draws on the professional notion at times, it is a distinct concept that applies only when the First Amendment is evoked in a public university context. After outlining the professional notion and the Supreme Court's dedication to academic freedom as a First Amendment right, I conclude Part I by discussing the current quagmire in the lower courts.

Part II scts forth a proposed framework for analyzing constitutional academic freedom that is consistent with both the Supreme Court's statements and the fundamental analysis motivating many lower courts' seemingly divergent approaches. First, I outline the "functional necessity" framework for public employees in general, and then I apply it specifically to the academic freedom context. In summary, once a court has decided that the state has a managerial interest in the speech of a public university professor, the operative question should be whether the regulation of the speech is functionally necessary to the realization of the institution's goals. In many situations, the professor's speech is not incompatible with these goals. In fact, where the university's goals are critical democratic education or the promotion of new discoveries, academic freedom is necessary to the institution's functioning. The proposed case-by-case analysis involves an investigation not only of the university's goals but also of the professor's role and the context of the speech. I conclude with an exposition of the benefits of the functional necessity approach.

Part III demonstrates that in Urofsky the Fourth Circuit erred in automatically deferring to the state, in failing to ask the operative question of functional necessity, and in distinguishing between "individual" and "institutional" academic freedom. These missteps in Urofsky's analysis led the court astray and resulted in the decision to deny individual professors a right of academic freedom. The decision in Urofsky may have been an understandable result in the existing disarray of academic freedom doctrine, but I conclude that it was an unnecessary and unfortunate development. Although the Supreme Court has not created an explicit academic freedom standard, it has given lower courts all the tools they need to analyze these important cases in a way consistent with its precedent and with the constitutional values at stake. 


\section{BACKgRound to Understanding THE ConcePt of ACAdEMIC FreEdom}

Although many courts and commentators simply refer to "academic freedom," proper analysis requires further specification of what type of academic freedom is being referenced. The term actually refers to two different concepts: "professional" academic freedom and "constitutional" academic freedom. ${ }^{7}$ The professional notion centers on professional ethics of self-governance and autonomy set forth by the AAUP. The constitutional notion, on the other hand, is legal rather than ethical and was developed by courts after professors began to sue for academic speech rights under the First Amendment. Although I focus on the constitutional notion in this Comment, it is important to understand this distinction in order to recognize when courts are drawing on the professional notion in fleshing out the constitutional notion and when courts are entirely diverging from the professional conception of academic freedom.

\section{A. The Development of "Professional" Academic Freedom: Professional Ethics Regarding Self-Government and Professorial Autonomy}

The foundation for the professional understanding of academic freedom in the United States is the AAUP's 1915 Declaration of Principles ${ }^{8}$ (later revised as the 1940 Statement of Principles). ${ }^{9}$ Borrowing from nineteenth century German notions of academic freedom (Lehrfreiheit), the 1915 Declaration pinpointed three key elements: "freedom of inquiry and research; freedom of teaching within the university or college; and freedom of extramural utterance and action." 10 In justifying such freedom, the

7. Walter Metzger, Profession and Constitution: Two Definitions of Academic Freedom in America, 66 TEX. L. Rev. 1265 (1988).

8. Am. Ass'n of Univ. Professors, 1915 Declaration of Principles, reprinted in ACAdemic Freedom ANd Tenure, app. A at 157-76 (Louis Joughin ed., 1969).

9. Am. Ass'n of Univ. Professors, i 940 Statement of Principles on Academic Freedom AND TENURE, AAUP Pol'y Documents \& REP. 3 (1984).

10. David M. Rabban, A Functional Analysis of "Individual" and "Institutional" Academic Freedom Under the First Amendment, 53 LaW \& ConTEMP. Probs. 227, 232 (1990). Arthur Lovejoy set forth the classic definition of this professional view of academic freedom:

Academic freedom is the freedom of the teacher or research worker in higher institutions of learning to investigate and discuss problems of his science and to express his conclusions whether through publication or in the instruction of students, without interfcrence from political or ecclesiastical authority, or from the administrative officials of the institution in which he is employed, unlcss his methods arc found by qualificd bodies of his own profession to bc clearly incompetent or contrary to professional ethics.

Arthur Lovejoy, Academic Freedom, in 1 ENCYC. Soc. SCl. 384 (Edwin Seligman \& Alvin Johnson eds., 1930). For thorough discussions of the history of the "professional" view of academic freedom, see Richard Hofstadter \& Walter P. Metzger, The Development of ACademic Freedom in THE United States (1955); Thomas L. Haskell, Justifying the Rights of Academic Freedom in the Era of Power/Knowledge, in The Future of ACademic Freedom (Louis Menand ed., 1996) (discussing origins and nature of the principlc of faculty self-governance); Metzger, supra note 7; Walter P. 
Declaration provided that the roles of university and professor relied on free inquiry. Specifically, it defined the role of professors as engaging in independent and expert scholarship and defined the role of universities as promoting inquiry and knowledge, instructing students in critical reasoning, and providing experts for public service. ${ }^{11}$ The Declaration specifically described the university as an "intellectual experiment station." 12 It then noted that these functions of the university and professor could not be sustained if untrained and self-interested boards of trustees reviewed and dictated professors' actions. ${ }^{13}$ For that reason, the Declaration provided for a norm of self-governance achieved by peer review and a norm of insulation for professors provided by a system of tenure. ${ }^{14}$ It characterized faculty members as "appointees" rather than "hired hands" and painted the relationship between the boards and the faculty as analogous to the relationship between the executive branch and appointed federal judges. ${ }^{15}$ According to the Declaration, if a university wished to be designated as a "true" university deserving of public support, ${ }^{16}$ it must have vowed to protect faculty freedom in this way and to maintain a stance of institutional neutrality. ${ }^{17}$

It is important to emphasize that this professional concept of academic freedom is purely a professional norm of ethics. It is not grounded in any constitutional or other legal right and is not specifically enforced by courts. ${ }^{18}$ The concept applies equally to private and public universities, so long as they have signed on to the 1915 Declaration (or the 1940 Statement). ${ }^{19}$

\section{B. The Development of "Constitutional" Academic Freedom: The Supreme Court's Dedication to Academic Freedom as a First Amendment Right}

After World War II, McCarthyism's onslaught provoked professors to seek protection from the courts for academic speech freedom within the

Metzger, The 1940 Statement of Principles on Academic Freedom and Tenure, 53 LAw \& ConTEMP. Probs. 3 (1990).

11. Rabban, supra note 10 , at 232 .

12. Id. at 237. For a good survey of traditional descriptions of the truth-seeking function and autonomous nature of American universities, see David Fellman, Academic Freedom in American Law, 1961 Wis. L. Rev. 3, 4-9 (1961). See also Arthur M. Cohen, The Shaping of American Higher Education: Emergence and Growth of the Contemporary System (1998).

13. Rabban, supra note 10, at 233-34.

14. See Metzger, supra note 7, at 1283.

15. Id. at 1279.

16. See Rabban, supra note 10, at 235. Due to the extensive lobbying of eminent professors at the time, most major universities signed on to the Declaration.

17. See Metzger, supra note 7, at 1279-80.

18. See William W. Van Alstyne, Academic Freedom and the First Amendment in the Supreme Court of the United States: An Unhurried Historical Review, 53 Law \& Contemp. Probs. 79 (1990), reprinted in Freedom and TeNURE IN THE ACADEMY (William W. Van Alstyne ed., 1993).

19. See Metzger, supra note 7, at 1280. 
university. The courts were under no obligation to constitutionalize or implement the professional ethics norm embodied by the AAUP Declaration. Instead, they turned to an obviously relevant legal norm: the First Amendment. Because one of the most frequently cited policies underlying the First Amendment is a desire to foster uninhibited public discourse by preserving a "marketplace of ideas," 20 it is no surprise that the Supreme Court located uninhibited academic expression within the parameters of this constitutional provision. Thus was born the distinction between the "professional" and "constitutional" notions of academic freedom. ${ }^{21}$

The Supreme Court's decisions in this area have provided a consistent set of principles linking academic freedom and the First Amendment, even though those principles are articulated in dicta. The first Supreme Court opinion to mention academic freedom is Justice Douglas's dissent in Adler v. Board of Education of City of New York. ${ }^{22}$ The majority upheld the Feinberg Law, which disqualified from public employment any person who belonged to communist organizations. ${ }^{23}$ Specifically, the majority held that a teacher could choose between membership in a communist organization and public school employment, but could be lawfully disqualified from the "privilege" of public employment if she made the wrong choiee. ${ }^{24}$

20. See, e.g., Red Lion Broad. Co. v. FCC, 395 U.S. 367, 390 (1969) ("It is the purpose of the First Amendment to preserve an uninhibited marketplace of ideas in which truth will ultimately prevail, rather than to countenance monopolization of that market....") (Holmes, J., dissenting). Justice Holmes, dissenting in Abrams v. United States, 250 U.S. 616, 630 (1919), noted:

But when men have realized that time has upset many fighting faiths, they may come to believe even more than they believe the very foundations of their own conduct that the ultimate good desired is better reached by free trade in ideas - that the best test of truth is the power of the thought to get itself aecepted in the competition of the market, and that truth is the only ground upon which their wishes safely can be carried out. That at any rate is the theory of our Constitution.

Id. See also N.Y. Times v. Sullivan, 376 U.S. 254, 270 (1964) (recognizing our "profound national commitment to the principle that debate on public issues should be uninhibited, robust, and wideopen"); Roth v. United States, 354 U.S. 476, 484 (1957) (noting that the First Amendment "was fashioned to assure unfettered interchange of ideas for the bringing about of political and social changes desired by the people"); United States v. Assoeiated Press, 52 F. Supp. 362, 372 (S.D.N.Y. 1943) (Hand, J.) (explaining that the First Amendment "presupposes that right conelusions are more likely to be gathered out of a multitude of tongues, than through any kind of authoritative selection. To many this is, and always will be, folly; but we have staked upon it our all'), aff' $d, 326$ U.S. 1 (1945).

21. Although the Court has drawn on the professional notion in fleshing out university missions and professorial functions when interpreting the First Amendment in the university context, the constitutional notion is conceptually distinct. For a gencral history of conceptions of constitutional academic freedom, see Metzger, supra note 7, and Van Alstyne, supra note 18. See also HofSTADTER \& Metzger, supra note I0; William P. Murphy, Academic Freedom-An Emerging Constitutional Right, 28 LAW \& ConTEMP. Probs. 447 (1963) (summarizing early cases). It is also important to note at the outset that constitutional academic freedom applies only to public universities and professors because the First Amendment restricts only state action. Metzger, supra note 7, at 1291 .

22. 342 U.S. 485 (1952) (Douglas, J., dissenting). The Court later invalidated the Feinberg Law. See Keyishian v. Bd. of Regents of Univ. of State of N.Y., 385 U.S. 589 (1967). However, the discussion of academic freedom in Justice Douglas's dissent is still relevant.

23. N.Y. Education LaW $\S 3022$ (McKinney 1949).

24. Adler, 342 U.S. at 492. 
In his dissent, Justice Douglas disagreed with the notion that public employees gave up their civil rights upon employment and penned an eloquent tribute to academic freedom. He wrote that the public school is the "cradle of our democracy," and the "very threat of [the Feinberg Law] is certain to raise havoc with academic freedom." 25 He cited no authority, tests, or standards, but rather referred to academic freedom as an established right. His policy explanation hinged on the importance of academic freedom in warding off tyranny: "What happens under this law is typical of what happens in a police state.... A pall is cast over the classrooms. There can be no real academic freedom in that environment. . . . Supineness and dogmatism take the place of inquiry. . . . Fear stalks the classroom."26 Justice Douglas then drew academic freedom into the First Amendment without pause: "The Framers knew the danger of dogmatism.... We forgct these teachings of the First Amendment when we sustain this law."27

Justice Frankfurtcr echoed this description of the link between acadcmic freedom and the First Amendment in his concurrence in Wieman v. Updegraff, in which the majority invalidated a statute that required state employees to take loyalty oaths. ${ }^{28}$ Justice Frankfurter noted that applying the statute to teachers "brings the safeguards of [the First and Fourteenth Amendments] vividly into operation," because a loyalty oath would "chill that free play of the spirit which all teachers ought especially to cultivate and practice." 29 This description brought academic freedom under the wing of the Constitution as a "limitation[] upon State and National power." Barenblatt v. United States ${ }^{31}$ and Shelton v. Tucker, ${ }^{32}$ the Court followed this language and declared academic freedom to be constitutionally protected..$^{33}$ And in Sweezy v. New Hampshire, the Court explained that

25. Id. at 508-09.

26. Id. at 510 .

27. Id. at 511 .

28. 344 U.S. 183 (1952).

29. Id. at 195 (Frankfurter, J., concurring).

30. Id. at 197.

31. 360 U.S. 109 (1959) (upholding conviction of tcacher for contempt of Congress after he refused to answer congressional questions during inquiry on communist infiltration in education).

32. 364 U.S. 479 (1960) (upholding teachers' challenge of statute requiring them to file affidavits identifying all organizations to which they had belonged within preceding five years as prerequisite to employment).

33. See Barenblatt, 360 U.S. at 112 ("When academic teaching-freedom and its corollary learning-freedom, so essential to the well-being of the Nation, are claimed, this Court will always be on the alert against intrusion... into this constitutionally protected domain."). In Shelton, the Court invalidated the teacher-loyalty statute on overbreadth grounds but still sang the praises of constitutionalized academic freedom: "The vigilant protection of constitutional freedoms is nowhere morc vital than in the community of American schools." Shelton, 364 U.S. at 487. 
liberties in the areas of academic freedom are clearly "areas in which government should be extremely reticent to tread." ${ }^{\prime 34}$

By 1967, the Court had come to refer to the notion of academic freedom as engrained in constitutional law and solidly linked to the First Amendment. For example, in Keyishian v. Board of Regents of University of State of New York, the Court invalidated a state employee loyalty statute on vagueness grounds but in the process provided forceful language on the value of academic liberty:

Our Nation is deeply committed to safeguarding academic freedom, which is of transcendent value to all of us and not merely to the teachers concerned. That freedom is therefore a special concern of the First Amendment, which does not tolerate laws that cast a pall of orthodoxy over the classroom. ${ }^{35}$

A few years later, the Court noted in Healy v. James that it was "break[ing] no new constitutional ground in reaffirming this Nation's dedication to safeguarding academic freedom." 36

This conception of constitutional academic freedom remains vital on the Supreme Court. As recently as 2000 , Justice Souter insisted, "We have long recognized the constitutional importance of academic freedom." 37 Justice Souter was correct: for almost half a century, the Supreme Court has emphasized that academic freedom should be constitutionally protected under the First Amendment.

\section{The Quagmire: Conflicting Approaches to Academic Freedom}

Although the Supreme Court has paid much homage to the ideal of First Amendment academic freedom, it has not outlined an explicit standard or definition of the scope of such a right ${ }^{38}$ The lack of clear guidance from the Supreme Court has led to myriad approaches by theorists and

34. 354 U.S. $234,250(1957)$.

35. 385 U.S. $589,603(1967)$.

36. 408 U.S. 169, 180-81 (1972) (holding that unsupported fear of disruption was insufficicnt to justify college's denial of recognition of Students for a Democratic Society). See also Whitehill v. Elkins, 389 U.S. 54 (1967) (striking down state law requiring teacher's oath). In Whitehill, the Court found a loyalty act to be overbroad and vague and therefore hostile to academic frecdom. Id. at 60 .

37. Univ. of Wis. v. Southworth, 529 U.S. 217,238 n.3 (2000) (Souter, J., concurring).

38. See, e.g., J. Petcr Byrne, Academic Freedom: A "Special Concern of the First Amendment," 99 YALE L.J. 251, 253 (1989) ("Lacking dcfinition or guiding principle, the doctrine [of academic frecdom] floats in the law, picking up dccisions as a hull does barnacles."); W. Stuart Stuller, High School Academic Freedom: The Evolution of a Fish out of Water, 77 NeB. L. Rev. 301, 302 (1998) ("[C]ourts are remarkably consistent in their unwillingness to give analytical shape to the rhetoric of academic freedom."). See also Rabban, supra note 10, at 230. Professor Rabban notes:

Unfortunately, the Supreme Court's glorification of academic freedom as a "special concern of the First Amcndment" has produccd hyperbolic rhetoric but only scant, and often ambiguous, analytic content. The Court has never cxplained systematically the theory behind its relatively recent incorporation of academic frecdom into the first amendment, a problem occasionally acknowledged by the justices themselves. 
lower courts, resulting in conflicting methodologies and unpredictable outcomes. For example, some courts utilize a "public forum" approach, ${ }^{39}$ some look to general First Amendment principles, ${ }^{40}$ some point to government subsidy ${ }^{41}$ or employee ${ }^{42}$ cases, and some simply create their own academic freedom standards. ${ }^{43}$ Commentators have advocated a variety of conflicting analytical routes overlapping with and departing from these judicial approaches. ${ }^{44}$ But they have been no more successful in reaching a consensus than the lower courts.

39. This approach derives from Hazelwood School District v. Kuhlmeier, 484 U.S. 260 (1988). See, e.g., Vanderhurst v. Colo. Mountain Coll. Dist., 208 F.3d 908, 914 (10th Cir. 2000) (assuming that correct approach would be to determine whether college's lcgitimate pedagogical interests in this nonpublic forum wcre "reasonably related" to regulation); Silano v. Sag Harbor Union Free Sch. Dist., 42 F.3d 719, 722-23 (2d Cir. 1994) (utilizing Hazelwood nonpublic forum "reasonable relationship" test); Vega v. State Univ. of N.Y., 67 F. Supp. 2d 324, 337 (S.D.N.Y. 1999) (holding that academie speech should be governed by Hazelwood nonpublic forum "reasonable relationship" test).

40. See, e.g., Cohen v. San Bernardino Valley Coll., 92 F.3d 968, 971 (9th Cir. 1996) (basing deeision on grounds of vagueness because Supreme Court had not defined scope of academic freedom).

41. See, e.g., Edwards v. Cal. Univ. of Penn., 156 F.3d 488, 491 (3d Cir. 1998) (analogizing to subsidy cases and concluding that public university professor "does not have a First Amendment right to decide what will be taught in the classroom" because state can "say what it wishes when it is the speaker").

42. This approach derives from Pickering v. Board of Education of Township High School District 205, Will County, Illinois, 391 U.S. 563 (1968). See, e.g., Trejo v. Shoben, 319 F.3d 878, 884 n.3 (7th Cir. 2003) (stating that academic freedom is subsumed under a general free speech claim and then analyzing the case as a public employee free speech claim); Bonnell v. Lorenzo, 241 F.3d 800 , 809-10 (6th Cir. 2001) (utilizing Pickering government employee approach); Dambrot v. Cent. Mich. Univ., 55 F.3d 1177, 1185-86 (6th Cir. 1995) (same).

43. See, e.g., Parate v. 1sibor, 868 F.2d 821, 827-28 (6th Cir. 1989) (performing straight balancing of governmental and professorial interests); Bishop v. Aronov, 926 F.2d 1066, 1074 (11th Cir. 1991) (focusing on whether regulation was rational in light of the "basic educational mission" of the school).

44. For example, some commentators argue in favor of using a traditional Pickering analysis for public employees in academic freedom cases. See, e.g., Stephen A. Newman, At Work in the Marketplace of Ideas: Academic Freedom, the First Amendment, and Jeffries v. Harleston, 22 J.C. \& U.L. 281 (1995); Harry F. Tepker Jr. \& Joseph Harroz Jr., On Balancing Scales, Kaleidoscopes, and the Blurred Limits of Academic Freedom, 50 OKLA. L. REv. 1 (1997). Howcver, others arguc against the Pickering approach. See, e.g., Ailsa W. Chang, Resuscitating the Constitutional "Theory" of Academic Freedom: A Search for a Standard Beyond Pickering and Connick, 53 STAN. L. Rev. 915 (2001); Richard H. Hiers, Academic Freedom in Public Colleges and Universities: O Say, Does That Star-Spangled First Amendment Banner Yet Wave? 40 WAYNE L. Rev. 1 (1993) (arguing that Pickering approaeh should not be applied automatically until changes in doctrine oecur). But see Richard H. Hiers, Institutional Academic Freedom vs. Faculty Academic Freedom in Public Colleges and Universities: A Dubious Dichotomy, 29 J.C. \& U.L. 35 (2002) (suggesting ways of accommodating academic freedom interests in Pickering approach). Additionally, some advocate the use of a rational basis test, see e.g., William G. Buss, Academic Freedom and Freedom of Speech: Communicating the Curriculum, 2 J. Gender RACE \& Just. 213 (1999); Gregory A. Clarick, Public School Teachers and the First Amendment: Protecting the Right to Teach, 65 N.Y.U. L. Rev. 693 (1990), while others disagree with such a standard. See, e.g., Theresa J. Bryant, May We Teach Tolerance? Establishing the Parameters of Academic Freedom in Public Schools, 60 U. PITT. L. Rev. 579 (1999). Some scholars draw the limiting distinction as between speech gearcd toward indoetrination, which would not be protected under academic freedom, and speech geared toward education, which would be protected. See, e.g., Burton M. Leiser, Threats to Academic Freedom and Tenure, 15 PACE L. REv. 15 (1994). Others would protect even indoctrinating speech, arguing that such 
However, the current quagmire does not result solely from the absence of explicit guidelines. Disagreement also stems from a fundamental confusion about the scope of academic freedom itself: should it apply only to claims of individual professors ("individual" academic freedom), only to claims of universities ("institutional" academic freedom), or to both? ? $^{45}$ Professor Matthew Finkin argues that academic freedom belongs only to the individual and is a concept distinct from institutional autonomy. ${ }^{46}$ Finkin contends that collapsing institutional and individual academic freedom into one notion erodes the concept of professorial autonomy and shields the university from exacting scrutiny.$^{47}$ In essence, he argucs that institutional autonomy should be a different concept from academic freedom, which should belong only to individual professors. ${ }^{48}$ In contrast, Professor J. Peter Byrne argues for a notion of "institutional academic freedom. ${ }^{" 49} \mathrm{He}$ argues that although early cases involved claims by individual professors, the Court was concerned not with university governance of professor speech but with interference by outside sources. ${ }^{50}$ After dismissing the significance of those early cases vis-à-vis individual professors' rights, Byrne moves to defining academic freedom as an institutional right. Because universities necessarily engage in viewpoint discrimination, Byrne asserts, the only real purpose of a constitutionalized academic freedom is to "protect academic values and practices from conformity to general [outside] social demands." ${ }^{11}$ In line with this institutional focus, he advocates a sort of good faith or rational basis test for reviewing the decisions of university officials against individual professors, ${ }^{52}$ and asserts that academic freedom, properly understood, refers only to the institution's autonomy. ${ }^{53}$

speech serves democratic values. See, e.g., Mark G. Yudof, When Government Speaks: Politics, LAW, aND GOVERNMENT EXPRESSION IN AMERICA (1983).

45. A good starting point for anyone who wishes to undcrstand the history and present status of this dichotomy is Hiers, supra note 44. See also Rabban, supra note 10.

46. Matthew W. Finkin, On "Institutional" Academic Freedom, 61 Tex. L. Rev. 817, 818 (1983).

47. Id. at 849-51.

48. See id; see also Elizabeth Mertz, The Burden of Proof and Academic Freedom: Protection for Institution or Individual?, 82 Nw. U. L. REv. 492, 519-20 (1988) (arguing that individual academic freedom rights should always trump claims of institutional autonomy, based on her reading of democratic theory).

49. See Byrne, supra note 38 .

50. Id. at 298 .

51. Id. at 307.

52. Id. at 308 (arguing that when faced with a claim of individual academic freedom, courts need only "ascertain if the administrators can establish that they in good faith rejected the candidate on academic grounds").

53. Id. at 255 . Byrne notes:

[T] he force of the non-legal tradition of academic freedom has been directed at protecting the professional autonomy of the individual professor when engaging in academic work within the university, but 1 believe that constitutional academic freedom should primarily insulate the university in core academic affairs from interference by the state. 
Urofsky v. Gilmore ${ }^{54}$ decided in 2000 , brought to the foreground this debate between advocates of individual and institutional academic freedom when the Fourth Circuit stated that public university professors have no individual right of academic freedom. In Urofsky, professors at public colleges and universities had challenged the constitutionality of a Virginia statute that restricted state employees from accessing sexually explicit material using state-owned computers. ${ }^{55}$ These professors desired access to this information in connection with research in their fields. After embarking on an analysis of the history of the academic freedom concept, the court concluded that " $[t]$ he Supreme Court, to the extent it has constitutionalized a right of academic freedom at all, appears to have recognized only an institutional right of self-governance in academic affairs." ${ }^{\circ 6}$ Indeed, the court noted, it "has never set aside a state regulation on the basis that it infringed a First Amendment right to academic freedom." 57 The court then explicitly "disagreed" with the idea that a First Amendment right of academic freedom belongs to the professor as an individual. ${ }^{58}$

Urofsky demonstrates the urgent need for clarity in this area of the law, because the confusion over academic freedom has now led to an outright denial of this right to public university professors. In this Comment, I argue that the confusion fueling Urofsky's unfortunate result is avoidable. As I describe below, although courts purport to apply different tests in academic freedom cases, many actually utilize the same analytical framework of functional necessity. Applying a functional necessity analysis of the Supreme Court's public employee jurisprudence to the academic arena allows constitutional academic freedom to be analyzed in a workable framework derived from constitutional principles. It also obviates the need for a sharp distinction between individual and institutional academic freedom in many common situations like those presented in Urofsky.

Id. See also Bruce C. Hafcn, Hazelwood School District and the Role of First Amendment Institutions, 1988 DUKE L.J. 685, 703 (1988) (arguing that academic freedom is meant to increase institutional autonomy to constrain destructive effects of rampant individualism); Metzger, supra note 7, at 1320 (noting that although early cases highlighted interdependence of individual and institutional academic freedom, the Court "wore institutional autonomy in their heart of hearts" because First Amendment already protected individual freedom).

54. 216 F.3d 401 (4th Cir. 2000).

55. Id. The First Amendment claims were brought under the Supreme Court's past decisions declaring that the right to speak includes the right to access and receive information. See Bd. of Educ. v. Pico, 457 U.S. 853, 867 (1982) (quoting Martin v. Struthers, 319 U.S. 141, 143 (1943)) ("[T]he right to receive ideas follows ineluctably from the sender's First Amendment right to send them: 'The right of freedom of speech and press ... embraces the right to distribute literature, and necessarily protects the right to receive it."'); Am. Library Ass'n. v. United States, 201 F. Supp. 2d 401, 451 n.21 (E.D. Pa 2002) ("The Supreme Court has recognized that the First Amendment encompasses not only the right to speak, but also the right to receive information.").

56. Urofsky, $216 \mathrm{~F} .3 \mathrm{~d}$ at 412 .

57. Id. at $411-12$.

58. Id. 


\section{A Functional Necessity Approach to Academic Freedom} Within the State's Managerial Domain

In this Comment, I argue that the best way to approach academic freedom cases in the public higher education context is to focus on the functional relationships among professors, universities, and the state. Such an approach takes into account concerns of both professors and universities in a way that is consistent with the Supreme Court's statements regarding the values behind protecting academic freedom. It also furthers constitutional values by protecting the greatest amount of speech possible. In this Part, I begin with a description of how the functional necessity approach can be applied to First Amendment claims in the general context of state institutions. ${ }^{59}$ After exploring the general framework, I then apply the approach to cases of academic freedom claims specifically within state institutions of higher education in an effort to define "constitutional academic freedom."

\section{A. Setting up the Framework: Public Employees' Rights in the State's Managerial Domain}

I begin this section by summarizing the framework before delving into the details: Courts must first determine whether the state has a managerial interest in its employee's speech. If the state has no such managerial interest, then the court should apply a normal citizen-oriented First Amendment analysis to the case. However, if the public employee has spoken within her capacity as an employee, then that speech may be less protected. The court should apply a functional necessity test to such speech, asking the operative question of whether the speech is basically incompatible with the goals of the state as a manager.

\section{Step One: The Threshold Characterization of the State as Either Governor or Manager-Determining Whether the State Has an Interest in a State Employee's Speech}

In Pickering v. Board of Education, ${ }^{60}$ the Supreme Court distinguished between speech made by state employees in their capacity as employees and speech made by state employees in their capacity as citizens. A school board had fired a high school teacher for sending a letter to a newspaper criticizing the school board's proposals to raise new revenue. Because "the fact of employment [was] only tangentially and insubstantially involved in the subject matter of the public communication

59. For a thorough explanation of this functional necessity approach to speech within state institutions in general, see Robert Post, Constitutional Domains: Democracy, Community, MANAGEMENT (1995).

60. Pickering v. Bd. of Educ. of Tp. High Sch. Dist. 205, Will County, Ill., 391 U.S. 563 (1968). 
made by a teacher," the Court concluded that it was "necessary to regard the teacher as the member of the general public he seeks to be" and apply normal First Amendment rules. ${ }^{61}$ The Court noted, however, that if the teacher had made the speech in his capacity as employee, the analysis would be different. Whereas Pickering's speech led the Court to conclude that, in this case, the "interest of the school administration in limiting teachers' opportunities to contribute to public debate is not significantly greater than its interest in limiting a similar contribution by any member of the general public," interests as an employer in regulating the speech of its employees that differ significantly from those it possesses in connection with regulation of the speech of the citizenry in general." ${ }^{.63}$

To understand why Pickering treats the state employee's speech as employee differently from his speech as citizen in the context of First Amendment analysis, consider the different roles of the state in each situation. When the state governs speech made by citizens in public discourse, it is strictly limited by ordinary First Amendment rules. This type of authority exercised over the general public can be labeled "governance" authority. ${ }^{64}$ However, as Professor Robert Post points out, when the state administers within its own institutions, its "managerial" authority is controlled by different First Amendment rules that allow the state to regulate in conformity with the "instrumental logic characteristic of organizations." ${ }^{, 65}$ Like other formal organizations, a state institution is established for the purpose of achieving certain goals, and managerial authority is necessary for it to accomplish those democratically determined goals. ${ }^{66}$

Therefore, when the state acts as a manager, it can restrict speech in ways that would be impermissible in its role as a governor. ${ }^{67}$ For example, although the state as governor is prohibited from engaging in viewpoint discrimination, the state as manager discriminates based on viewpoint all

61. Id. at 574 .

62. Id. at 573 .

63. Id. at 568 .

64. Robert C. Post, Between Governance and Management: The History and Theory of the Public Forum, 34 UCLA L. Rev. 1713, 1775 (1987).

65. Id. (explaining that when government acts within its managerial authority, "ordinary first amendment rights are subordinated to the instrumental logic characteristic of organizations" and that when state "manages" within its own institutions, it "can in large measure control speech on the basis of an organization's need to achicve its institutional ends").

66. Id. at 1769. See also Buss, supra note 44, at 230 ("The government that is responsible for schools and colleges, like government generally, is created to do things.").

67. See, e.g., Int'l Soc'y for Krishna Consciousness, Inc. v. Lee, 505 U.S. 672, 678 (1992) ("Where the government is acting as a proprietor, managing its internal operations, rather than acting as lawmaker with the power to regulate or license, its action will not be subjected to the heightened revicw to which its actions as a lawmaker may be subject."). See also Post, supra note 64, at 1775 . 
the time.$^{68}$ Running an institution would be impossible without such decisions: without viewpoint discrimination, teachers could not grade students and Senators could not assign position papers to employees. ${ }^{69}$

Drawing the line between the state's governance realm and its managerial realm is therefore the key first step of the analysis. Importantly, the Court in Pickering did not make a distinction based on whether the speech was made off-hours or off-campus. The Court made no such distinction because the state's managerial realm is not determined by easy reference to the geographical or temporal boundaries that often define organizational authority. ${ }^{70}$ Rather, the constitutional view of state management is grounded in the notion that within state institutions, predetermined goals are a given. ${ }^{71}$ This method of goal-setting is different from that within the operation of democratic public discourse in the state's governance realm, where goals are not taken as assumed value premises but are created through discussion and debate. ${ }^{72}$ Therefore, the constitutional distinction between management and governance "turns on the priority accorded to proposed objectives," 73 and the boundaries of the state's managerial realm "can be recognized by the predominance of functionally defined organizational roles." ${ }^{\prime 74}$ If the court recognizes such preset state goals and functionally defined roles within the context in which the speech was made, then the speech occurs within the state's managerial realm.

\section{Step Two: The Operative Question-Determining Whether the Regulation of a State Employee's Speech Is Functionally Necessary to Accomplish the State's Legitimate Managerial Goals}

The fact that a state employee may be speaking within the state's managerial realm does not mean that the speech is not protected. In Pickering, the Court ruled that if speech is deemed to be within the state's managerial realm, the court must next conduct a balancing test whereby the

68. See Robert C. Post, Subsidized Speech, 106 YALE L.J. 151, 166 (1996). Post notes that in managerial settings

speech is necessarily and routinely constrained on the basis of both its content and its viewpoint. Academic evaluations of students and faculty are regularly based upon viewpoint. Historians who deny the Holoeaust are not likely to reeeive appointments to reputable departments; students who deny the legitimacy of the taxing power of the federal government are not likely to reeeive high grades in law schools.

Id. Therefore, Harry Tepker and Joseph Harroz seem mistaken when they insist that the Pickering balance must incorporate a prohibition on viewpoint discrimination. See Tepker \& Harroz, supra note 44 , at 34-39. The entire point of looking to a different test for government employees is that in the managerial realm the government must have a freer hand than it has in governing the public at large. Otherwise, it could not aceomplish its democratieally determined goals.

69. Sec Post, supra note 68, at 166; see also Post, supra note 64, at 1768.

70. See id. at 1785-88.

71. Id. at 1789.

72. Id.

73. Id.

74. Id. at 1793. 
court strikes a balance between the free speech interests of the employee and the managerial interests of the state. ${ }^{75}$ Despite the Court's reference to the proper analysis as a "balancing test," however, the Court's subsequent approaches to public employee speech involved not a balancing act per se but rather an instrumental calculation. ${ }^{76}$ That is, instead of truly balancing the interests of the state and speaker, the Court has calculated whether restriction of the speech is necessary for the realization of institutional goals. ${ }^{77}$ Where the regulation of the public employee's speech is functionally necessary to the state's goal, the state's interest trumps the employee's interest and the courts undertake no balancing test at all. On the other hand, if restriction of the speech is not functionally necessary, the employee's speech interest prevails.

Several cases demonstrate that the Court has not been utilizing the balancing scales but rather has engaged in the instrumental calculation of whether a speech regulation is functionally necessary to the state institution's goals ${ }^{78}$ For example, in Connick v. Myers, the Court noted that full consideration must be given to the "government's interest in the effective and efficient fulfillment of its responsibilities to the public," and that "the Government, as an employer, must have wide discretion and control over the management of its personnel and internal affairs." 79 In this case, the government's stated justification for restricting the employee's speech was to maintain close working relationships. The Court stated that "[w]hen close working relationships are essential to fulfilling public responsibilities, a wide degree of deference to the employer's judgment is appropriate." ${ }^{, 80}$ Rather than balancing one interest against the other, the Court then explained that the central question was whether the speech actually would disrupt such working relationships. ${ }^{81}$ Essentially, the Court held that the restriction on Connick's speech was necessary for the

75. Pickering v. Bd. of Educ. of Tp. High Sch. Dist. 205, Will County, lll., 391 U.S. 563, 568 (1968). The Court first named and applied the Pickering balancing test in Connick v. Myers, 461 U.S. 138, 156-57 (1983).

76. See Post, supra note 64, at 1814 n.351.

77. Id. In all of the cases discussed herein, the institution itself determines its goals and brings them to the Court as justification for the restriction of speech. See, e.g., Tinker v. Des Moincs Indep. Cmty. Sch. Dist., 393 U.S. 503, 509 (1969) (holding that school officials must justify speech regulation by evidence that speech substantially interferes with educational goals). The Court may determine that such goals are not legitimate ones for the particular institution, either because they are not reasonably related to the institution's commonly understood mission or bccause they violate other constitutional or statutory provisions. See discussion infra note 236 . However, such determinations are rare, and state institutions are generally free to define their own missions in these cases.

78. Post, supra note 64, at 1814 n.351. See also Connick, 461 U.S. at 154 (holding that state institution's regulation of Connick's speech did not "offend" First Amendment because speech would "disrupt the office, undermine [her supervisor's] authority, and destroy close working relationships").

79. 461 U.S. at 150 (citations omitted).

80. Id. at $150-51$.

81. Id. at 152 . 
attainment of the legitimate institutional goals of maintaining close working relationships. ${ }^{82}$ Similarly, in Rankin v. McPherson, which involved a county employee's offhand remark about a presidential assassination attempt, the Court's holding turned on the conclusion that "there [wa]s no evidence that [the remark] interfered with the efficient functioning of the office. $" 83$

This functional necessity view of the government employee cases is consistent with other Supreme Court precedent regarding speech in state institutions. For example, in Grayned v. City of Rockford, the Court relied on the premise that the government can suppress speech only when that speech may interfere with the use of governmental property. ${ }^{84}$ Similarly, in Tinker v. Des Moines Independent Community School District, the Court insisted that only in-school speech that causes a "substantial disruption" in the educational process may be suppressed. ${ }^{85}$ In Healy $v$. James, the Court held that a university need not tolerate "[a]ssociational activities ... where they infringe reasonable campus rules, interrupt classes, or substantially interfere with the opportunity of other students to obtain an education." ${ }^{\prime 86}$ And in Brown v. Glines, the Court held that "[s]peech likely to interfere with ... vital prerequisites for military effectiveness ... can be excluded from a military base." ${ }^{87}$ In short, whenever the Court is faced with a free speech claim within the state's managerial realm, it does not balance interests, but instead engages in the instrumental calculation of whether the regulation is necessary for the institution to achieve its objectives. ${ }^{88}$ This test follows from the general First Amendment policy that the state ought to tolerate the greatest amount of speech possible within its managerial limitations. ${ }^{89}$

In determining whether a speech regulation is functionally necessary to institutional goals, the Supreme Court has stated that the crucial question is whether the expression is "basically incompatible" with the government's goals..$^{90}$ This analysis considers the role of the employee, the facts surrounding the speech, the location of the speech, and whether the

82. Post, supra note 64, at 1810 n.351.

83. 483 U.S. 378,389 (1987). In Rankin, the Court also asserted: "Vigilance is necessary to ensure that public employers do not use authority over employees to silence discourse, not because it hampers public functions but simply because superiors disagree with the content of employees' speech." Id. at 384.

84. 408 U.S. 104 (1972).

85. 393 U.S. 503, 514 (1969). See also Buss, supra note 44, at 225 (noting similarity between Tinker and Pickering, as both focus on whether speech substantially disrupts workings of government institution).

86. 408 U.S. $169,189(1972)$.

87. 444 U.S. $348,354(1980)$.

88. Post, supra note 64 , at 1770.

89. Id. at 1780; see also infra notes $186-87$.

90. Grayned v. City of Richmond, 408 U.S. 104, 116 (1972). 
employee spoke for the institution. ${ }^{91}$ Each of these factors affects the degree to which the state institution's goals will be undermined by the employee's expression. For example, in Connick $v$. Myers, the Court emphasized the importance of the context in which the speech was made. ${ }^{92}$ The Court considered the timing of the office questionnaire, the surrounding events, the addressees, and the method of dissemination and concluded that this context demonstrated that the employee's questionnaire would be likely to disrupt the state employer's functioning. ${ }^{93}$ And in Rankin $v$. McPherson, the Court explained that in determining whether an employee's speech thwarts the mission of the public employer, courts must scrutinize the role of the public employee..$^{94}$ Rankin also emphasized the distinction between employee speech "in" an institution and employee speech "for" an institution, with the latter being more likely to undermine state missions. Because the employee in that case served no "public contact role," the likelihood that her speech would be understood as being for the institution was extremely low..$^{95}$ Therefore, harm to the state's managerial goals was also low, and restriction of the employee's speech was unlikely to be functionally necessary. ${ }^{96}$

Thus, despite the Court's references to a "balancing test," the operative question in public employee cases is whether the speech restriction is functionally necessary to the institution's goals. Answering this operative question involves determining the nature of these goals, the role of the employee, and the context and nature of the employee's speech. Before turning to the application of this functional necessity approach to academic freedom cases, I next outline the circumstances under which courts properly defer to the state's managerial judgments.

\section{When Judicial Deference to the State's Managerial Judgment Is Warranted}

The above discussion of the two main steps of the functional necessity approach to speech within state institutions does not tell the whole story. Any exposition of this approach would be incomplete without a brief explanation of when courts decline to embark on independent judicial review in the first place. At times, a court may not even reach the substantive test

91. See Newman, supra note 44, at 305 ("Determining whether the employee's speech is harmful depends upon careful examination of the function of the government agency, the position of the employee in the agency, and the nature of the employee's statement.").

92. 461 U.S. 138, 152-53 (1983).

93. Id.

94. 483 U.S. 378, 390 (1987) ("[I]n weighing the State's interest in discharging an employee based on any claim that the content of a statcment made by the employee somehow undermines the mission of the public employer, some attention must be paid to the responsibilities of the employee within the agency.").

95. Id. at $390-91$.

96. Id. at 391 . 
outlined above. Rather, the court may "defer" to the state and trust the state to follow the court's First Amendment standards.97

Deference is never automatieally warranted. Instead, the decision whether to defer to the state depends on the relationship between the governmental institution and its members. ${ }^{98}$ In some institutions, deferenee is warranted because the act of judicial review would harm this relationship. ${ }^{99}$ For example, in Brown v. Glines, the Court deferred to the government because the nature of a military base is such that "the right to command and the duty to obey ordinarily must go unquestioned."100 Thus, the Court chose not to scrutinize whether the plaintiff's particular petition would interfere with military effectiveness; instead, it focused on the potential damage to military authority that would occur if courts were to engage in the practice of independently reviewing military commands. ${ }^{101}$ Brown can be contrasted with Tinker, where the Court refused to defer to school authorities in the regulation of student expression. ${ }^{102}$ Unlike the military, a high school does not need unquestioned state authority such that the simple act of judicial review would harm that authority. In fact, the goal of the high school in Tinker was explicitly to teach skills of reasonable dissent and instill "the independence and vigor of Americans who grow up and live in this relatively permissive, often disputatious, society." 103 Deference was unwarranted because independent judicial review would not harm the authority wielded by the school. Under Brown and Tinker, a court's determination of whether deference is appropriate in a given case depends on analysis of how independent judicial review would harm the relationship between the institution and its members. In no other case is judicial deference to the state appropriate under the functional necessity view of public employee speech jurisprudence.

\section{Summary}

In this Comment, I advocate the adoption of a reformulated view of the Supreme Court's public employee and state institution jurisprudence. Under this approach, courts first determine whether the employee's speech is made in her role as a citizen or in her role as an employee. If it is made in her role as an employee, then courts analyze whether restriction of the speech was functionally necessary to the accomplishment of the university's goals, or, in other words, whether the speech was basically incompatible with such goals. In rare situations in which the act of independent

97. See Post, supra note 64, at 1810.

98. Id. at 1772.

99. Id.

100. 444 U.S. at 357.

101. Post, supra note 64, at 1772.

102. See Tinker v. Des Moines Indep. Cmty. Sch. Dist., 393 U.S. 503, 509 (1969).

103. Id. 
judicial review would harm the state's unquestioned authority over its institutional members, courts decline to investigate functional necessity and defer to the state. However, automatic deference is never warranted.

\section{B. Applying the Functional Necessity Approach to Academic Freedom}

Having sketched out the functional necessity approach to First Amendment claims in the context of state institutions in general, I now turn to applying this framework to the specific instance of academic freedom claims within state institutions of higher education. In the following section, I describe how lower courts use university goals and professor roles in determining whether to vindicate a claim of academic freedom. Although the courts purport to apply a variety of tests, often including some variant of Pickering balancing, most of the analysis actually stays true to the managerial framework outlined in Part I.A above. When conducting the functional necessity analysis, where the university's goals are primarily either critical democratic education or the fostering of new discoveries, academic freedom is a neccssary condition for the accomplishment of these goals. In these situations, restriction of professors' speech thwarts realization of the school's mission. It is in these cases that academic freedom must be vindicated as a First Amendment right in an institutional context. Where the university's goals are incompatible with the professor's expression, however, regulation of the speech is found to be functionally necessary and the professor's claim of academic freedom fails. I then analyze these cases against the backdrop of the Supreme Court's academic freedom dicta to build a definition of constitutional academic freedom. I conclude this section with a brief discussion of the benefits of utilizing this approach in academic freedom cases.

\section{Determining When Professors Speak Within the State's Managerial Domain}

Just as they do when faced with general public employee speech claims, courts facing academic freedom claims should first decide whether the state has a managerial interest in the expression. As explained earlier, the Pickering Court drew a bright line between a public employee's speech as a citizen and her speech as an employee. ${ }^{104}$ If the state has no interest in the speech, then it is deemed to be citizen speech and normal First Amendment rules apply to heavily scrutinize the state's invasion into public discourse. ${ }^{105}$ The speech in Pickering, for instance, was a letter that a teacher had sent to a newspaper. The Court held that the state had no different interest in this speech than it would have in a nongovernment-

104. See discussion supra Part 11.A.1

105. See Pickering v. Bd. of Educ. of Tp. High Sch. Dist. 205, Will County, 111., 391 U.S. 563, 574

(1968). 
employee citizen's speech, ${ }^{106}$ because the speech was "only tangentially and insubstantially involved" with the teacher's employment. ${ }^{107}$ Where a court determines that a professor's speech, like the letter in Pickering, constitutes citizen speech in which the state lacks any special interest, the claim is not properly one of academic freedom but rather one of freedom of speech generally. In those situations, the state is restricted to the same extent that it would be in silencing citizen speech outside of its managerial institutions.

However, the state has an interest in much professorial speech. A public university professor's job duties are determined within the university according to predetermined objectives and needs, and will usually include some form of teaching, lecturing, advising, researching, and writing within a particular field of study. Therefore, whenever a professor gives a lecture or engages in scholarship within her field of expertise, a court will likely find her to be acting in a way related to her job duties. In these cases in which the professor speaks within the state's managerial domain, the analysis departs from the usual First Amendment rules governing citizens. It is in these situations that the concept of constitutional academic freedom takes on any meaning.

\section{Determining the Operative Question of Functional Necessity in the Academic Arena}

After finding that the academic speech lies within the state's managerial domain, a court should ask whether the restriction of the professor's speech is functionally necessary to accomplish the university's goals. ${ }^{108}$

106. Id.

107. Id. Similarly, in United States v. National Treasury Employees' Union, 513 U.S. 454, 465 (1995), the Court clarified that one of the ways to draw the line between a public employee's speech made in the employee's capacity as a citizen and that made in her capacity as an employee is to examine how related the speech is to the employee's job duties. Specifically, the Court stated that "[i]n Pickering and a number of other cases we have recognized that Congress may impose restraints on the job-related speech of public employees that would be plainly unconstitutional if applied to the public at large." Id. This "job-related" approach can be viewed as simply one way of determining whether the state is according priority to its predetermined objectives, or, in other words, whether it is acting within its managerial authority according to its institutional ends. See discussion supra Part II.A.1.

108. See discussion supra Part II.A.2; see also Robert C. Post, Constitutionally Interpreting the FSM Controversy, in The Free Speech Movement: Reflections on Berkeley in the I 960 os 401, 403 (Robert Cohen \& Reginald E. Zelnick eds., 2002) (noting that state universities are government organizations with managerial objectives and therefore courts should analyze free speech of students under functional necessity test: "the First Amendment has consistently been interpreted to permit the regulation of speech within state organizations where necessary to achieve legitimate organizational ends"); Robert C. Post, Racist Speech, Democracy, and the First Amendment, 32 WM. \& MARY L. Rev. 267,318 (1990). In discussing racist speech on college campuses, Post notes that the

constitutionality of [hate speech] regulation depends upon the logic of instrumental rationality, and specifically upon three factors: (1) the nature of the educational mission of the university; (2) the instrumental connection of the regulation to the attainment of that mission; and (3) the deference that courts ought to display toward the instrumental judgment of institutional authorities. 
Before conducting such a functional analysis, it is therefore necessary to investigate the goals of the university ${ }^{109}$ and the role of the professor. The two are necessarily interrelated, as the professor's proper function will be determined by the university's goals. This section explores a number of possible approaches to this analysis as a preliminary step to clarifying where academic freedom fits into the functional necessity equation.

\section{a. Goals of the University}

There are many ways to characterize the goals of a public educational institution, but some general themes emerge from the case law. The Supreme Court has pointed out that a major goal of American schools is to train future leaders "through wide exposure to that robust exchange of ideas which discovers truth out of a multitude of tongues, rather than through any kind of authoritative selection." 110 This goal is often expressed by designating the classroom as "peculiarly the marketplace of ideas." 111 Under this view, the Court sees training future leaders in reasoned public discourse as necessary for the maintenance of a democratic society. ${ }^{112}$ Here, I categorize and label this particular goal as one of "critical democratic education." Another important goal of educational institutions recognized by the Court is the generation of "new discoveries"113 in natural sciences, social sciences, and other areas of scholarship. ${ }^{114}$ Educational institutions generally also aim to inculcate fundamental norms of civility, especially at the primary and secondary level. ${ }^{115}$ Finally, because few of the other educational missions could be achieved in a state of chaos, an

\section{Id.}

109. Although this section of the Comment focuses on cases in which universities act against professors, the same approach would be appropriate for a case in which the state acts directly against the professor as an cmployee. Instead of examining the university's goals, however, we would investigate the state's goals in managing professors as employees. The state's goals will often be the same as the university's goals but may sometimes differ. For example, many of the McCarthy-era cases involved state goals of censoring communist study that conflicted with university goals.

110. Keyishian v. Bd. of Regents of Univ. of State of N.Y., 385 U.S. 589, 603 (1967) (citation omitted). See also Cooper v. Ross, 472 F. Supp. 802, 811 (E.D. Ark. 1979) (noting that the "college classroom is peculiarly suited to the "robust exchange of ideas"' (citing Keyishian, 385 U.S. at 603)).

111. Keyishian, 385 U.S. at 603.

112. See, e.g., Sweezy v. New Hampshire, 354 U.S. 234, 262 (1957) (emphasizing the "dependence of a frce society on free universities"); Wieman v. Updegraff, 344 U.S. 183, 196 (1952) (Frankfurter, J., concurring) (noting that because democracy rests on "disciplined and responsible" public opinion, "[ $t]$ he process of education has naturally enough been the basis of hope for thc perdurance of our democracy on the part of all our great leaders, from Thomas Jefferson onwards"); Hardy v. Jefferson Cmty. Coll., 260 F.3d 671, 679 (6th Cir. 2001) (noting educational goal of "prepar[ingl students for their place in society as responsible citizens" by "teach[ing] students the process of rational discourse"). See also Fellman, supra note 12, at 6 ("A democratic society cannot function successfully without an enlightened public opinion emanating from an educated citizenry.").

113. See Sweezy, 354 U.S. at 250.

114. Id. at 261 .

115. Bethel Sch. Dist. No. 403 v. Fraser, 478 U.S. 675, 683 (1986) (noting that it is the work of the schools to demonstrate to students which modes of expression are "inappropriate"). 
overarching goal will always be to ensure that "the discipline necessary to the proper functioning of the school is maintained among both teachers and students." 116 Other commentators have classified these goals somewhat differently, ${ }^{117}$ but the goals noted above embrace the main purposes commonly attributed to, and advocated by, universities. ${ }^{118}$

\section{b. Role of the Professor}

The professor's function and the university's goals are interrelated for purposes of this analysis. Thus, each of the educational goals discussed above entails a different function or role for the professor, depending on the context of the case. For example, where the school's goal is to teach civility norms, the teacher's function becomes that of a role model. ${ }^{119} \mathrm{But}$ where the school's goal is to facilitate democratic public discourse, the teacher's function is to be the "priest of our democracy" in taking up the "special task" of "foster[ing] . . open-mindedness and critical inquiry." 220

116. James v. Bd. of Educ. of Central Dist. No. 1 of Towns of Addison et al., 461 F.2d 566, 571 (2d Cir. 1972).

117. For example, Byrne has distilled the possible educational goals into two main categories: "humanistic" goals, which are geared toward nurturing and training students in morals and civility norms, and "democratic" goals, which focus on social mobility and prosperity. See Byrne, supra note 38, at 279-81. Post has suggested three different concepts of the mission of public education: (1) "democratic education," which "understands the purpose of public education to be the creation of autonomous citizens, capable of fully participating in the rough and tumble work of public discourse"; (2) "civic education," which "conceptualizes instruction as a process of cultural reproduction, whereby community values are authoritatively handed down to the young"; and (3) "critical education," which is most often associated with universities and "views the university as an institution whose distinctive 'primary function' is 'to diseover and disseminate knowledge by means of research and teaching."' Post, supra note 108, at 319-22. Finally, Professor Mark G. Yudof has opted for a version of "democratic" education:

While doubtless there is no consensus on their ordering, their precise meaning, and how they should be applied in particular instances, the democratic ideal presumably embodies such values as tolerance, civility, liberty, equality, respect for individual dignity, participation in political decisions, freedom of expression, freedom to own and dispose of property, and respect for minority interests.

YuDOF, supra note 44, at 54.

118. Although First Amendment doctrine allows the educational institution to define its own goals to the court, only rarely will the university deviate greatly from those mentioned above and instead insist that its goals are to indoctrinate non-free thinking students or to stifle innovation. This is one area in which courts often draw upon the professional notion of academic freedom, since most major universities have defined their educational missions in line with the 1915 Principles of free inquiry and critical thinking. See discussion supra Part 1.A. It may seem that because First Amendment jurisprudence gives wide latitude to the state or university to define its goals, such an approach inadequately protects professors (as goals can be manipulated). Howcver, it is important to remember that constitutional academic freedom is only part of the picture; the notion of professional academic freedom will often pick up where constitutional academic freedom leaves off. It is true that the vindication of the professor's First Amendment rights will turn on the state's definition of its goals, but this is how the First Amendment operates in state institution jurisprudence. Although the Court will determine if the state's goals are "legitimate," see infra note 236, the other safeguard here is the university's adherence to professional academic norms.

119. Fraser, 478 U.S. at 683 (1986).

120. Wieman v. Updegraff, 344 U.S. 183, 196 (1952). 
And where the goal is to foster new discoveries, the teacher's role is to be "fearless" in engaging in "hypothesis and speculation." 21 In each case, the professor's role will determine the level of protection of her academic speech, because courts facing academic freedom claims allow a public university to restrict such academic expression only when it is functionally neeessary to do so-in other words, where the professor's expression is "basically incompatible" 122 with the university's goals.

By examining the circumstances under which courts find restrictions on academic speech to be necessary, we can see where constitutional academic freedom exists. In this section, I describe five lower court cases that purport to use different tests and frameworks but that actually implicitly utilize the same test of functional necessity as outlined above. After explaining how each court engages in similar analysis behind the scenes, I then turn to analyzing these cases against the backdrop of the Supreme Court's academic freedom dicta to build a definition of constitutional academic freedom.

A good place to begin an illustration of lower courts' implicit functional analyses is by examining two Sixth Circuit cases involving restriction of professors' speech. In Hardy v. Jefferson Community College, a professor used the offensive words "nigger" and "bitch" during a discussion in his Introduction to Interpersonal Communication class. ${ }^{123} \mathrm{He}$ had designed this particular lesson to demonstrate how "language is used to marginalize minorities and other oppressed groups in society" and how certain words "have historically served the interests of the dominant culture in which they arise." 24 An African American student complained, and the college failed to renew Hardy's contract. After noting that Hardy's speech fell on the managerial side of Pickering's line, ${ }^{125}$ the court investigated Hardy's role in light of the college's goals. First, the court explained that "the essence of a teacher's role is to prepare students for their place in society as responsible citizens," 126 citing Gregory Clarick's statement that teachers must "teach[] students the process of rational discourse that allows them to participate meaningfully in public debate." 127 The court then recognized the goal of "promoting efficiency in the educational services that it provides and in avoiding disruption to its operations." 28 Although it purported to balance the professor's academic freedom interests against the

121. Sweezy v. New Hampshire, 354 U.S. 234, 261-62 (1957).

122. Grayned v. City of Richmond, 408 U.S. 104, 116-17 (1972).

123. 260 F.3d 671,672 (6th Cir. 2001).

124. Id. at 675 .

125. Id. at 678 .

126. Id. at 679.

127. Clarick, supra note 44 , at 702.

128. Hardy, $260 \mathrm{~F} .3 \mathrm{~d}$ at 681 . 
college's interests, ${ }^{129}$ the court really performed a functional calculation. It ruled that beeause Hardy's speech comported with the school's goal of teaching students to participate in open democratic public discourse in a way that was germane to the curriculum, and was not incompatible with the school's goal of avoiding disruption and inefficiency, it was not functionally necessary to restrict Hardy's academic expression. ${ }^{130}$

The Sixth Circuit reached a different result when the university's goal was characterized not as teaching students to think critically, but to train them in basic skills. In Hetrick v. Martin, ${ }^{131}$ Eastern Kentucky University failed to renew Professor Hetrick's contract because of its displeasure with her pedagogical attitude. The court stated that "[w]hatever may be the ultimate scope of the amorphous 'academic freedom [right],", it knew the case would not fall under its protections because otherwise every nontenured teacher could claim insulation from review by her superiors. ${ }^{132}$ However, although this court essentially purported to be without guidance or precedent, once again it implicitly followed the functional necessity test after investigating the university's goals. The court first stated that the university "considered the students as generally unsophisticated and as having 'somewhat restricted backgrounds,' and for this reason apparently expected the teachers to teach on a basic level, to stress fundamentals and to follow conventional teaching patterns-in a word, to 'go by the book." 133 This goal is very different from the college's democratic public discourse goal as described by the court in Hardy. Therefore, the professor's act of teaching students "how to think rather than merely to accept and to parrot what they had heard," 134 as manifested in ambiguous assignments and insufficient treatment of assigned texts, was inconsistent with the college's goal. ${ }^{135}$ Specifically, the court explained that Hetrick's "teaching philosophy and the manner in which she implemented it were not adaptable to the achievement of the academic goals of the University."136 Although

129. Id. at 680 .

130. Id. at $681-82$. The court noted that because the school had only an "undifferentiated fear of disturbance" in this case, and no disturbance actually occurred, Hardy's "rights to free speech and academic freedom" prevailed. Id. at 682. Citing Pickering, the court noted that the relevant considerations are

whcther an employee's comments meaningfully interfere with the performance of his duties or with the employer's general operations, undermine a legitimate goal or mission of the employcr, create disharmony among coworkers, undercut an immediate supervisor's discipline over the employee, or destroy the relationship of loyalty and trust required of confidential employees.

Id. at $680-81$.

131. 480 F.2d 705 (6th Cir. 1973).

132. Id. at 709 .

133. Id. at 707 .

134. Id.

135. Id.

136. Id. 
the court noted that such an educational goal may not be entirely wise, the right of academic frecdom "does not cncompass the right of a nontenured teacher to have her teaching style insulated from review" by the university ${ }^{137}$ In short, the court held that restricting the professor's speech was functionally necessary to the accomplishment of the school's goal of "teaching the basics."

The Second Circuit in Jeffries $v$. Harleston ${ }^{138}$ explicitly stated that it was performing a Pickering balance, but then discussed the role of the professor as part of an implicit functional necessity calculation of an academic freedom claim. Jeffries was a Black Studies professor who, after being introduced as the chairman of the college's Black Studies department, gave a controversial off-campus speech criticizing curricular choices. In rcsponse to the speech, the university removed him from his department chairmanship. The court decided that Jeffries had made the speech in his capacity as a department chair, rather than as a professor. ${ }^{139}$ The court then emphasized that the position of department chair at City University of Ncw York ("CUNY") is ministerial. ${ }^{140}$ Because the university only removed Jeffries's ministerial duties, ${ }^{141}$ rather than "silenc[ing] him, or otherwise limit[ing] his access to the "marketplace of ideas' in the classroom," the court held that Jeffries's academic freedom had not been infringed. ${ }^{142}$ In essence, the court found that the university had more administrative control over a professor acting in the role of administrator than it had over a professor acting in the role of maintaining a "marketplace of ideas." Restricting Jeffries's speech was functionally necessary to the university's administrative goal of maintaining CUNY's reputation because there was a reasonable expectation that the off-campus speech would harm CUNY. ${ }^{143}$

137. Id. at 709 .

138. 52 F.3d 9 (2d Cir. 1995).

139. Id. at 14.

140. Id.

141. An earlier, related opinion deseribed the department chair's position as "an essentially ministerial role: He keeps department records, assigns courses to teachers, represents the department at internal CUNY meetings, drafts department budget proposals, leads departmental meetings, and makes departmental tenure evaluations." Jeffries v. Harleston, 2 l F.3d 1238, 1247 (2d Cir. 1994).

142. Jeffries, 52 F.3d at 14-15.

143. Id. at 13. See Newman, supra note 44, at 318-28 (analyzing Jeffries). Although Newman mistakenly advoeated the use of a balancing test, he correctly noted that government employers may dismiss workers for speech if the employer can

make a credible argument that the speech interfered with the operations or mission of the workplace. Determining whether the employee's speech is harmful depends upon a careful examination of the function of the government agency, the position of the employee in the agency, and the nature of the employee's statement.

Id. at 305. Newman then chastised the Jeffries court for failing to detail the harms to the university resulting from Jeffries's speech in a way that recognized the special characteristics of the university environment. $I d$. at $318-28$. Jeffries can bc viewed as similar to a very recent Seventh Circuit case, Trejo $v$. Shoben, 319 F.3d 878 ( 7 th Cir. 2003), in which a professor made lewd remarks at social events surrounding an academic conference. In Trejo, the court first noted that academic freedom claims are subsumed under general First Amendment interests, $i d$. at $884 \mathrm{n.3}$, and then proceeded to analyze the 
In Dambrot v. Central Michigan University, ${ }^{144}$ the Sixth Circuit noted that the motivations behind the Pickering analysis were similar to motivations animating the concept of academic freedom, but still analyzed the academic freedom claim separately and without any explicit tests. However, its analysis hinged on evaluating the functional necessity of regulating a teacher's speech in his role as coaeh versus his role as teacher. ${ }^{145}$ Dambrot was the head coach of the university's basketball program. In a locker-room session with his players, he used the word "nigger" to inspire them to be "fearless, mentally strong and tough" both in and out of the classroom. ${ }^{146} \mathrm{He}$ claimed a right of academic freedom because his use of the word was to "instruct[] them about how they should be playing basketball and about how they should behave in the classroom."147 The court noted that although the principle of academic freedom emphasizes the importance of free public expression of ideas, ${ }^{148}$ this principle was not implicated in this case:

Dambrot's use of the N-word is ... [far] away from the marketplace of ideas and the concept of academic freedom because his position as coach is somewhat different from that of the average classroom teacher. Unlike the classroom teacher whose primary role is to guide students through the discussion and debate of various viewpoints in a particular discipline, Dambrot's role as a coach is to train his student athletes how to win on the court. The plays and strategies are seldom up for debate... Moreover, the coach controls who plays and for how long, placing a disincentive on any debate with the coach's ideas which might have taken place. ${ }^{149}$

Dambrot was hired to coach, not to foster critical debate. Because his use of the word was not intended to foster debate in light of his role, the court held that academic freedom did not come into play. His speech was incompatible with the university's goal of maintaining a discriminatory harassment policy and it was thus functionally necessary to restrict Dambrot's speech made in his capacity as a coach.

case as involving a public employee free speech claim. In denying the professor's claim, the court emphasized the difference between the role of a professor teaching a class and the role of a professor at social cvents surrounding a conference. $I d$. at 887 (finding that cven though the statements were in professor's field of study, there is great difference between those made at event and those made while "leeturing to students in a classroom setting on a topic relevant to their field of study"). The professor's statements were not made while he was in a pedagogical role, id., and they "disrupted the educational process and tarnished the University's good name." Id. at 890 .

144. 55 F.3d 1177 (6th Cir. 1995).

145. Id.

146. Id. at 1180 .

147. Id: at 1188 (italics omitted).

148. Id.

149. Id. at 1190 . 
Finally, in Piarowski v. Illinois Community College District 515, ${ }^{150}$ the Seventh Circuit purported to follow a nonpublic forum approach but actually followed the intuitions of the functional necessity framework. Piarowski, the chairman of a college art department, claimed that the school had violated his First Amendment academic freedom rights when it directed him to relocate his sexually explicit art to an alternative, less prominent site on campus. ${ }^{151}$ The court first determined that Piarowski's art was indeed within the managerial realm ${ }^{152}$ and thus the college had "more control over his activities than over a stranger's, but not unlimited control." 153 Second, the court noted that the university's goal was to avoid "convey[ing] an image of the college that would make it harder to recruit students, especially black and female students." 154 It emphasized the importance of focusing on the university's goals when it stated: "If we hold that the college was forbidden to take the action that it took to protect its image, we limit the freedom of the academy to manage its affairs as it chooses."155 In analyzing the functional necessity of the college's restriction of Piarowski's spcech, the court focused on several factors, the most notable of which were Piarowski's role as an administrator and the prominent location of the art. ${ }^{156}$ These circumstances could have indicated college approval, ${ }^{157}$ so there was some likelihood that the college's recruiting goals would be impaired. Because the college did not restrict more expression than was functionally necessary to achieve its recruiting goals, ${ }^{158}$ the court held that the regulation was constitutional.

These five cases show that although lower courts purport to be utilizing different tests in deciding claims of professorial academic freedom, many implicitly apply the functional necessity standard and make the university's goals and the professor's role central to their determinations. ${ }^{159}$ In the next section, I draw on these cases and on the Supreme Court's

\footnotetext{
150. 759 F.2d 625 (7th Cir. 1985).

151. Id.
}

152. The court explicitly recognized the need for "managerial judgment" in this situation. Id. at 630.

153. Id.

154. Id. at 630 .

155. Id.

156. Id. at 631 .

157. The court stated,

If the college had done nothing it might have been thought to be endorsing the windows by allowing them to be displayed so prominently right off the main thoroughfare, and near the main entrance, of the college. Piarowski's positions as chairman of the art department and gallery coordinator, to the extent known, would enhance the impression of official approval. Id.

158. The court notcd that "relocation is not supprcssion," $i d$. at 630 , and "good alternative sites" were available to Piarowski. $I d$. at 632.

159. See also Clarick, supra note 44 , at 728 ("The goals of public education and a teacher's proper role within the educational process thus should limit the types of interests a state can articulate to justify restrictions on that teacher's speech."). 
academic freedom dicta to build a definition of constitutional academic freedom consistent with the state's managerial authority in educational institutions.

\section{Defining Constitutional Academic Freedom: First Amendment Rights in an Institutional Context}

Understanding how lower courts have implicitly applied a type of functional necessity test in academic speech cases makes it easier to flesh out what courts mean when they say "constitutional academic freedom." When one vicws these lower court cases against the backdrop of the Supreme Court's relevant guiding language, it becomes clear that constitutional academic freedom embodies a particular operation of the First Amendment in the particular institutional context of a university. I turn now to analyzing this dicta in the search for a definition, and then I reconcile the result with the five lower court cases.

Since the first judicial mention of academic freedom in Justice Douglas's dissent in Adler, the Supreme Court has justified the concept by reference to particular missions of public educational institutions. In Adler, Justice Douglas noted that one of the goals of a school was to serve as the "cradle of our democracy" 160 by fostering "bold and adventuresome" thinking, ${ }^{161}$ rather than "producing students trained as robots." ${ }^{162} \mathrm{He}$ asserted that an environment without academic freedom "produces standardized thought, not the pursuit of truth. Yct it was the pursuit of truth which the First Amcndment was designed to protect." ${ }^{163} \mathrm{He}$ insisted that the Framers had this goal of critical democratic education in mind when they deployed the First Amendment against the "danger of dogmatism." 164 He stated that training students to be rational contributors to public discourse was necessary to "our way of life." $165 \mathrm{He}$ also referred to the university's goal of producing scholarship and new discoveries, noting that without academic freedom, "supineness and dogmatism take the place of inquiry" and "[a] problem can no longer be pursued with impunity to its edges." 166 Therefore, Justice Douglas clearly situated academic freedom as a necessary

\footnotetext{
160. Adler v. Bd. of Educ. of City of N.Y., 342 U.S. 485, 508-09 (1952) (Douglas, J., dissenting).

161. Id. at 511 .

162. Id.

163. Id.

164. Id. Justice Douglas noted:

A school system producing students trained as robots threatens to rob a generation of the versatility that has been perhaps our greatest distinction. The Framers knew the danger of dogmatism; they also knew the strength that comes when the mind is free, when ideas may be pursued wherever they lead. We forget these teachings of the First Amendment when we sustain this law.

165. Id.

166. Id. at 510 .
}

Id. 
condition for the achievement of the goals of critical democratic education $^{167}$ and the promotion of new discoveries, both of which are fundamental to a democratic society.

This view of academic freedom as a necessary condition for the accomplishment of two types of educational goals is consistent with other Supreme Court pronouncements. For example, in his concurrence in Wieman, ${ }^{168}$ Justice Frankfurter explicitly linked academic freedom to the goal of critical democratic education. First, he noted that "our democracy ultimately rests on public opinion," but that "public opinion is the ultimate reliance of our society only if it be disciplined and responsible." $169 \mathrm{He}$ continued: "It can be disciplined and responsible only if habits of open-mindedness and of critical inquiry are acquired in the formative years of our citizens." ${ }^{\prime \prime 70}$ For this reason, he exalted education as the hope of democracy's perseverance and referred to teachers "in our entire educational system, from the primary grades to the university[,] as the priests of our democracy." ${ }^{171} \mathrm{He}$ then explained that when the university's goal is that of critical democratic education or unfettered scholarship, the goal itself acts as a "limitation[] upon State and National power." 172 He further explicitly identified academic freedom ${ }^{173}$ as an "essential condition [for the] effective discharge" of those educational concerns and as a concern that falls within the purview of the First Amendment. ${ }^{174}$

Similarly, in his concurrence to Sweezy v. New Hampshire, Justice Frankfurter explained that a professor's academic freedom must be protected when the university has as its goal the promotion of scholarship and

167. See supra text accompanying notes $110-12$, describing critical democratic education as the goal of training students to be critical participants in public discourse.

168. Wieman v. Updegraff, 344 U.S. 183, 194 (1952) (Frankfurter, J., concurring).

169. Id. at 196.

170. Id.

171. Id. Justice Frankfurter noted:

It is the special task of teachers to fostcr those habits of open-mindedness and critical inquiry which alone make for responsible citizens, who, in turn, make possible an enlightened and effective public opinion. Teachers must fulfill their function by precept and practice, by the very atmosphere which they generate; thcy must be exemplars of opcn-mindedness and free inquiry. They cannot carry out their noble task if the conditions for the practice of a responsible and critical mind are denied to them. They must have the freedom of responsible inquiry, by thought and action, into the meaning of social and economic ideas, into the checkered history of social and economic dogma.

Id.

172. Id. at 197.

173. Id. Here, Justice Frankfurter pointed to independent thought and criticism within the university as the "essential conditions for cffcctive discharge" of the "functions of educational institutions." Id.

174. Id. at 196-97. Justice Frankfurter noted that teachers

must be free to sift evanescent doctrine, qualified by time and circumstance, from that restless, enduring process of extending the bounds of understanding and wisdom, to assure which the freedoms of thought, of speech, of inquiry, of worship are guaranteed by the Constitution of the United States against infraction by national or State government. 
new discoveries. ${ }^{175}$ Because "[i]nsights into the mysteries of nature are born of hypothesis and speculation," he noted that "[p]olitical power must abstain from intrusion into this activity of freedom, pursued in the interest of wise government and the people's well-being, except for reasons that are cxigent and obviously compelling." $176 \mathrm{He}$ explicitly described academic freedom as a "necessary condition[] for the advancement of scientific knowledge," as well as "necessary for creative work in the arts."177 The Sweezy majority also identified academic freedom as necessary to achieve the goals of critical democratic education and the promotion of new discoveries, which it characterized as crucial to our nation's survival. ${ }^{178}$ And in Keyishian v. Board of Regents of University of State of New York, the Court stated that the goal of maintaining the classroom as a marketplace of ideas and an incubator for critical democratic education necessitates academic freedom. ${ }^{179}$

Viewed in this light, the Justices' opinions are more than just poetic flourish; they define academic freedom as a particular result of a functional calculation of the university's goals and the professor's corresponding role. Specifically, the Justices found academic freedom to be necessary to the functioning of the university whenever the university's primary goals consisted of promoting new discoveries through scholarship or training students in critical thinking and reasoned public discourse. If we combine this insight in the academic freedom cases with the Court's general approach to speech in state institutions, it is important to remember that this is not a balancing test but an instrumental calculation. If the professor's speech is basically incompatible with the university's goals offered to justify the restriction, the professor will not prevail. But if the university's primary goals in the particular case are either critical democratic education or the promotion of new discoveries through seholarship, academic freedom will be necessary to the university's functioning.

This clarification of the Justices' views of academic freedom demonstrates that they are in harmony with the results reached in the lower court cases discussed above. In Hetrick v. Martin, the university's goal was to convey basics to "unsophisticated" students with "restrictive

175. 354 U.S. 234, 261-62 (1957) (Frankfurter, J., concurring).

176. Id. He continued: "For society's good-if understanding be an essential need of societyinquiries into these problems, speculations about them, stimulation in others of reflection upon them, must be left as unfettered as possible." Id.

177. Id. at 263.

178. Id. at 250. The Court emphasized that

the essentiality of freedom in the community of American universities is almost self-evident. No one should underestimate the vital role in a democracy that is played by those who guide and train our youth. To impose any strait jacket upon the intellectual leaders in our eolleges and universities would imperil the future of our Nation. No field of education is so thoroughly comprehended by man that new discoveries cannot yet be made. 
backgrounds," 180 so limiting the professor's speech was necessary to the functioning of the institution. Academic freedom was not necessitated by the university's mission; it was seen as hindering rather than advancing the stated goal. Similarly, in the Dambrot and Jeffries cases, the colleges' goals of coaching and administration defined the professors' roles not as "priests of our democracy" fostering a marketplace of ideas for critical reasoning or new discoveries, but rather as a coach who dictated strategy ${ }^{181}$ and an administrator who performed ministerial tasks. ${ }^{182}$ In these cases, academic freedom was not necessary to the accomplishment of the universities' goals. However, in Hardy v. Jefferson Community College, ${ }^{183}$ because one of the main goals of the college was to foster democratic public debate, restricting the professor's speech frustrated that goal. The court acknowledged the "robust tradition of academic freedom"184 and asserted that freedom of speech in the academic arena must be protected unless doing so would threaten a "substantial disturbance" to the school's daily functioning. ${ }^{185}$ In such cases, where restriction of the professor's speech is not functionally necessary and academic freedom is actually needed to achieve one of the main educational goals of the college, a professor's claim of academic freedom should be successful.

\section{Benefits of the Functional Necessity Approach to Academic Freedom}

There are two major benefits to following the functional necessity approach to academic freedom outlined in this Comment: it protects more speech than the alternatives do, and it is motivated by the constitutional values that stand behind the Supreme Court's statements on protecting academic freedom in the first place. This approach also alleviates the concern that professors should not have "special rights." Additionally, it accommodates the flipside of this concern: the argument that professors should indeed have special rights. In this section, I consider each of these benefits in turn.

Because one of the main objectives of the First Amendment is to ensure "uninhibited, robust, and wide-open" public debate, ${ }^{186}$ the best approach for regulating speech will protect the greatest amount of speech possible. ${ }^{187}$ It is thus a great benefit that the functional necessity approach

180. 480 F.2d 705, 707 (6th Cir. 1973).

181. Dambrot v. Cent. Mich. Univ., 55 F.3d 1177, 1190 (6th Cir. 1995).

182. Jeffries v. Harleston, 52 F.3d 9, 15 (2d Cir. 1994).

183. 260 F.3d 671, 679 (6th Cir. 2001).

184. Id. at 680 .

185. Id. at 681-82. Although the court in Hardy acknowledged the university's goal of maintaining order and efficiency, it found that restricting Hardy's speech was not necessary to accomplish that goal. Id. at 679-80.

186. N.Y. Times v. Sullivan, 376 U.S. 254, 270 (1964).

187. See, e.g., Martin H. Redish, Freedom of Expression: A Critical analysis, 118-19 (1984) (noting that First Amendment requires courts to balance interests "with 'a thumb on the scales" 
protects more speech than other alternatives. ${ }^{188}$ For example, the categorical nature of public forum doctrine ${ }^{189}$ protects less speech than does this managerial view of government employee speech because it does not focus on the speech itself. ${ }^{190}$ Instead, public forum doctrine "appears to invite the superfluous suppression of speech"191 by focusing on the type of property on which the speech occurred. If the characteristics of the property do not fit the "public forum" category, the government can prohibit speech even if it does not interfere with the government's use of the property in any way. In contrast, the functional necessity approach allows the government to prohibit only the amount of speech necessary for the accomplishment of the government's goals. ${ }^{192}$ Similarly, this approach protects more speech than a rational basis analysis, which would allow the government to ban any speech with a regulation for which it can provide any conceivable rational basis. ${ }^{193}$ The functional necessity approach, on the other hand, would

in favor of speech"); Steven H. Shiffrin, Dissent, InJustice and the Meanings of America 10 3I (1999) (arguing that dissent constitutes First Amendment's central purpose and that courts should interpret Free Speech Clause to encourage and facilitate dissent); Clarick, supra note 44, at 732 (noting that any approach to academic freedom should involve using "least restrictive manner available"); Charles R. Lawrence III, If He Hollers Let Him Go: Regulating Racist Speech on Campus, 1990 DuKE L.J. 43I, 452-53 (1990) (noting that principal purpose of First Amendment is to encourage greatest amount of speech possible).

188. Obviously, the most speech-protective alternative would be to afford academic speech the normal First Amendment protection that citizens enjoy in public discourse. However, as described earlier, this alternative is not available here because of the state's need to engage in content and viewpoint discrimination in managing its own institutions. See discussion supra Part II.A.l.

189. A court using a public forum approach views the characteristics of the government-owned property on which the speech takes place as either public or nonpublic. As the Court noted in Perry Education Ass' $n$ v. Perry Local Educators' Ass'n, "[i]n places which by long tradition or by government fiat have been devoted to assembly and debate, the rights of the State to limit expressive activity are sharply circumscribed." 460 U.S. 37, 45 (1983). However, if this type of governmentowned property has not traditionally been open to public expression, it is a nonpublic forum, and the government restriction need only be "reasonable in light of the purpose served by the forum." Cornelius v. NAACP Legal Def. \& Educ. Fund, 473 U.S. 788, 806 (1985); see also Post, supra note 64, at 1764 ("For all practical purposes, public forum doctrine is presently a blank check for government control of public access to the nonpublic forum for communicative purposes."). Recent cases have held that even in nonpublic forums, the government should not discriminate based on viewpoint. See, e.g., Lamb's Chapel v. Ctr. Moriches Union Free Sch. Dist., 508 U.S. 384 (1993). But as discussed earlier, viewpoint discrimination in nonpublic forums happens frequently. Schools have traditionally been nonpublic forums, but the Court's characterization of school property usually depends on the nature of the space itself. For example, classrooms and faculty offices are nonpublic, but common areas may be public or limited public forums. For a good exposition of the history and development of public forum doctrine, see Post, supra note 64, at 1718-65. See also Daniel A. Farber \& John E. Nowak, The Misleading Nature of Public Forum Analysis: Content and Context in First Amendment Adjudication, 70 VA. L. REv. 1219 (1984).

190. See Post, supra note 64, at 1766.

191. Id.

192. See id. (stating that functional approach "is designed to maximize the speech which the government is constitutionally required to tolerate, consistent with the appropriate and needful use of its property").

193. See, e.g., R.A.V. v. City of St. Paul, 505 U.S. 377, 406 (1992) (stating that unprotected speech need only pass rational basis review under the Equal Protection Clause, which would only 
not allow the state to restrict its employees' or professors' speech simply because it has formulated some rational basis for doing so; rather, the state must show that the restriction was functionally necessary because the speech was incompatible with the state's goal. ${ }^{194}$ Because it protects more expression than thcsc alternatives, the functional necessity approach is preferable.

Another major benefit of the functional necessity approach is that it follows logically from the constitutional values at stake. The most desirable doctrine is always that which is most directly motivated by the values behind the constitutional. rule. For example, if the purpose of the constitutional rule is to prevent unwarranted searches and seizures of citizens' private places, the best doctrine will allow only those searches justified by governmental reasons consistent with that constitutional rule. A doctrine that allowed warrantless searches of apartments, but not houses, would be an undesirable doctrine based on arbitrary line drawing; the government might come up with some reason that owners of apartments are more likely to be hiding contraband, but the doctrine would not be motivated by the values behind the particular constitutional rule. A better doctrine would be one that only allowcd warrantless searches of places in which the defendant had no reasonable expectation of privacy. Similarly, the purpose of the constitutional rule at issue in this Comment, the First Amendment, is to prevent unwarranted intrusions into free expression. Therefore, the most desirable doctrine will allow only those intrusions that are justified by a good governmental reason related to the value of protecting the speech in the first place.

An example of a First Amendment approach that does not follow from the constitutional value of protecting speech is traditional public forum doctrine. Remember that public forum doctrine hinges on the characterization of property; regardless of the expression's content or the governmental reasons for restricting it, speech made on property traditionally open to the public receives very high protection, and speech made on property traditionally closed to the public receives minimal protection. Therefore, the

require that the regulation of the speech "be rationally related to a legitimate government interest"). This standard of review is similar to Byrne's deferential standard, under which courts need only ascertain whether the university rejected the candidate in good faith on grounds rationally related to academic goals. See Byme, supra note 38, at 308.

194. Similarly, this approach would protect more speech than any type of reasonable relationship test, which would allow the state's restriction so long as it were reasonably relatcd to an educational goal. See, e.g., Int'l Soc'y for Krishna Consciousness, Inc. v. Lee, 505 U.S. 672, 678 (1992) (stating that speech regulations in nonpublic forums "must survive only a much more limited review" and "need only bc reasonable"); Hazelwood Sch. Dist. v. Kuhlmeier, 484 U.S. 260, 273 (1988) (stating that restriction of school-sponsored speech in nonpublic forum need only be "reasonably related to legitimate pedagogical concerns"). The functional necessity test would not permit the state to restrict speech merely because a reasonable relationship existed between the state's regulation and the goal. The stricter standard of the functional necessity test requires that the speech actually be incompatible with the goal. 
approach is both under- and over-inclusive. As Professors Daniel Farber and John Nowak state:

Classifying a medium of communication as a public forum may cause legitimate governmental interests to be thoughtlessly brushed aside; classifying it as something other than a public forum may lead courts to ignore the incompatibility of the challenged regulations with first amendment values. ${ }^{195}$

They conclude that public forum doctrine is undesirable because it takes attention away from the First Amendment values at stake by focusing on the characteristics of the property, rather than the value of the speech. ${ }^{196} \mathrm{In}$ other words, public forum doctrine is unfit as a First Amendment doctrine because it fails to focus on speech and the governmental justification for its regulation. ${ }^{197}$

Whereas public forum doctrine is divorced from the constitutional values behind protecting the speech at issue, the functional necessity test is specifically motivated by those values. This approach focuses on the nature of the government's authority in its managerial domain and logically links that authority to the value of speaking within that domain. It forces courts to focus on the relationship betwcen the speech and the reasons for its regulation. ${ }^{198}$ The functional necessity approach is consistent with the Supreme Court's pronouncements regarding the constitutional values behind the protection of speech, both in general public employee speech situations and academic freedom contexts.

The functional necessity approach to academic freedom also alleviates the concern that academic freedom somehow confers a special right on one class of public employees but not on others. ${ }^{199}$ It clarifies that academic freedom is not a special right but rather the result of a functional application of the First Amendment in the context of a particular governmental institution. ${ }^{200}$ Professors simply perform different roles for the university

195. See Farber \& Nowak, supra note 189 , at $1223-24$.

196. Id. See also Clarick, supra note 44, at 727-28 ("As the school speech arena plainly reveals, public forum analysis transforms constitutional inquiries regarding the value of certain speech into inquiries aimed at the characterization of a particular place. Such a focus subjugates constitutional values to questions of locus.").

197. See Post, supra note 64, at 1766.

198. Id.

199. See Rabban, supra note 10, at 246 ("[S]pecial treatment for a particular occupation or institution, even if analytically sound under general first amendment principles, creates understandable skcpticism, especially given the accurate perception that citizens have rights to equal protection under the first amendment.").

200. Although Rabban does not fit academic freedom within a public employee framework, he provides an apt summation of this point:

The argument for a constitutional right of academic freedom can be substantially strengthened by viewing it not primarily as a special right unique to professors, but as a specific application of the broader principle that the institutional context of speech often has first amendment significance. Under this approach, constitutional academic freedom is simply a convenient name to describe special speech rules governed by the functions of professors 
than do other types of employees. Under the functional necessity approach, this difference in roles results in differing levels of First Amendment protection, depending on the situation. As the court in Jurgensen v. Fairfax County, Virginia stated, professors are at the opposite end of the "spectrum" from police officers. ${ }^{201}$ The court noted that "[s]tate inhibition of academic freedom is strongly disfavored," and that such freedom is in "polar contrast" to the "discipline demanded of, and the freedom correspondingly denied to[,] policemen." ${ }^{202}$ Different treatment is required because the government's goals in managing police officers and universities will often differ dramatically. ${ }^{203}$ Although the levels of freedom may be different, the framework remains the same. Just as a police officer's speech should be restricted only when functionally necessary to the police department's goals, a professor's speech may be restricted only when functionally necessary to the university's goals. Academic freedom will be a necessary condition for the accomplishment of some of these goals.

The functional necessity approach also responds to the opposite concern: the argument that academic freedom should indeed be a special right. For example, Professor William Van Alstyne argues in favor of a "special theory" or "specific theory" of academic freedom rather than a "general theory" of the type advocated here. In Van Alstyne's view, any general theory "subjects [academic freedom] to the same explanation of employment accountability to which general civil liberties sometimes are made to yield, even when the case for protecting freedom of professional academic endeavor may be far stronger." ${ }^{204} \mathrm{He}$ argues that injury to university function should not justify restricting academic freedom, since the profession's role is to further critical public discourse; any injury to the university, as opposed to the profession, is merely the "cost" of academic

and universities, just as other special speech rules, which may not have been separately named, are required by the distinctive yet different functions of institutions as varied as prisons, libraries, the military, the civil service, [and] public schools... [F]irst amendment protections vary with institutional context.

Id. at 246-47.

201. 745 F.2d 868, 880 (4th Cir. 1984).

202. Id.

203. Byme is thus incorrect when he says that the First Amendment "does not distinguish among professors, prosecutors, or janitors." See Byrne, supra note 38, at 264 . Similarly, his view that "professors at state universities have no greater (or lesser) right to participate in political affairs than do other government employees," id., contradicts the functional approach the Supreme Court engages.

204. William W. Van Alstyne, Reply to Comments, in The CONCEPT OF ACADEMIC FreEDOM 125 , 127 (Edmund L. Pincoffs ed., 1975). Here, Van Alstyne is replying to John Searle's advocacy of the "general theory" of academic freedom as set forth in John R. Searle, Two Concepts of Academic Freedom, in The Concept OF ACAdemic Freedom 86 (Edmund L. Pincoffs ed., 1975). Searle defines this general theory as follows:

The basic principle of the general theory of academic freedom is that professors and students have the same rights of free expression... in their roles as professors and students that they have as citizens in a free society, except insofar as the mode of exercise of these freedoms needs to be restricted to prescrve the academic and subsidiary functions of the university.

Id. at 92 . 
freedom. ${ }^{205}$ Van Alstyne calls for the creation of a distinct First Amendment category of academic freedom, one different from the principles used to analyze free speech in an institutional or public employee context. He justifies the creation of this new category by pointing out that professors are accountable to higher standards of care in their speech and expected to engage in unfettered scholarship. ${ }^{206}$

However, the functional necessity approach addresses much of Van Alstyne's concern and realistically fits First Amendment jurisprudence in a way that Van Alstyne's theory cannot. Even though the functional necessity framework is identical to the one used in other public employee cases, professors will indeed end up with freedom in more instances than will other public employees because the court using the functional necessity approach considers the unique characteristics of a professor's role. Van Alstyne is correct that "the academic institution is meant to be different from other institutions in respect to its very raison d'être," ${ }^{207}$ but the functional necessity approach makes ample room for this difference. Van Alstyne's argument that professors should have a special academic freedom-one different from normal First Amcndment application in public institutions and unfettered by institutional concerns-is also incompatible with both the reality of university management and the established jurisprudence of the Supreme Court. ${ }^{208}$

The functional approach is preferable, then, because it accounts for the practicalities of university management in a way that reconciles the Supreme Court's public employee jurisprudence with its academic freedom dicta. Moreover, it is the best route of analysis because it alleviates concerns about academic freedom's being a "special right," because it protects

205. Van Alstyne, supra note 204, at 127-28.

206. William W. Van Alstyne, The Specific Theory of Academic Freedom and the General Issue of Civil Liberty, in The CONCEPT of ACAdEMic Freedom 71, 76-77 (Edmund L. Pincoffs ed., 1975). See also Byrne, supra note 38, at 259-60. Byrne stresses that the values of academic speech are very different from the values of speech in society at large:

[T] he value of academic speech rests on its commitment to truth,... its honesty and carefulness, its richness of meaning, its doctrinal freedom, and its invitation to criticism. ... In society at large, freedom of speech insulates from penalty expression that is vulgar, pernicious, incomprehensible, and mad.

Id. See also Ronald Dworkin, Freedom's Law: The Moral Reading of the American CONSTITUTION 247 (1996) (explaining appeal of treating acadcmic freedom "as just the application of the more general right to the special case of academic institutions," but concluding that it would "obscure much that is special about academic freedom. Free spcech ... doesn't provide for everyone what academic freedom provides for scholars"); Ronald Dworkin, We Need a New Interpretation of Academic Freedom, in The Future of ACademic Freedom 184 (Louis Mcnand ed., 1996) (same).

207. Van Alstyne, supra note 204, at 129.

208. To the extent that Van Alstyne wishes for a separatc sort of freedom justified by, and accountable to, the "fiduciary standard of professional integrity" and "professional ethical standards of truthful disclosure and reasonable care," Van Alstyne, supra note 206, at 71, his theory is more consistent with the professional AAUP notion of academic freedom than with the constitutional eoneept vindicated in the courts. See discussion supra Parts l.A.-B. 
more speech than other approaches do, and because it is specifically motivated by the most important constitutional values at stake. ${ }^{209}$

\section{III}

\section{WHERE UROFSKY WENT WRONG}

Had the Fourth Circuit used a functional necessity approach in Urofsky, it would not have categorically denied constitutional academic freedom to professors. Understanding just whcre the Urofsky court went wrong will help to further clarify the benefits and proper application of the functional necessity approach. Urofsky involved professors at public colleges and universities who challenged the constitutionality of a Virginia statute restricting state employees from accessing sexually explicit material on state-owned computers. ${ }^{210}$ The court, in denying their claims, insisted that any constitutional right of aeademie freedom always belongs to the institution, and never to individual professors. ${ }^{211}$ Although the court eorrectly located the issue as one within the state's managerial domain, each point of reasoning thereafter was flawed. In this Part, I first investigate the Urofsky court's failure to analyze the operative question of functional necessity. Then I explain where the court went wrong in distinguishing between institutional and individual academic freedom and denying the existence of the individual right.

\section{A. The Urofsky Court's Failure to Investigate the Operative Question of Functional Necessity}

The Urofsky court was correct to begin its analysis by drawing the line between state employee speech and citizen speech according to Pickering. It found that because the professors' expression was related to their

209. The approach of this Comment also alleviates the concerns raised by scholars who are troubled by reducing the university's special concerns to those of "workplace efficiency" under Pickering and Connick. See, e.g., Chang, supra note 44, at 939-40. Chang notes that "efficiency" may not take into consideration "the underlying academic mission of an educational institution" and suggests that

it seems there is still something greater at stake for a university than mere workplace efficiency.... To squeeze these unique, multifaceted considcrations under the single heading of workplace "efficiency" in a Pickering balancing test is to completely disregard the most important objectives and "special characteristics" of the particular public employer involved in an academic speech case.

Id. See also Walter P. Metzger, Professional and Legal Limits to Academic Freedom, 20 J.C. \& U.L. I, 7 (1993) (expressing concern that "academic freedom is engaged in a seesaw battle with workplace efficiency"). The functional necessity approach discussed herein explicitly takes these unique educational interests into account by focusing on efficiency in meeting the institution's specific function or goal. This broader view of efficiency is what the Connick Court had in mind. See Connick v. Myers, 461 U.S. 138, 150 (1983) (requiring "full consideration of the government's interest in the effective and efficient fulfillment of its responsibilities to the public").

210. Urofsky v. Gilmore, 216 F.3d 401 (4th Cir. 2000).

211. Id. at 412 . 
employment duties, the state had a managerial interest therein. ${ }^{212}$ However, the court then concluded that because the speech at issue was "clearly made in the employee's role as employee," and the state "must retain the ability to control the manner in which its employees discharge their duties," the court must automatically defer to the state. ${ }^{213}$ This is clearly wrong. As discussed earlier, deference is warranted only if independent judicial review will harm the particular managerial relationship between the state institution and its members. ${ }^{214}$ Automatic deference contradicts the Supreme Court's numerous statements that public employees retain First Amendment rights within the managerial realm. ${ }^{215}$

The Urofsky court's automatic deference blinded it to the correct path of First Amendment analysis. Nowhere in its opinion did the court determine the university's goals or the professor's function. Nor did it analyze whether the state's speech regulation was necessary to accomplish its goals. In fact, the court specifically stated: "That an enactment may be utterly unnecessary... does not affect its validity as a matter of constitutional law." 216 Even though the operative constitutional question in public employee cases is whether the regulation is functionally necessary to the state's goals, Urofsky incorrectly insisted that the necessity of a regulation is irrelevant. The court's failure to ask the operative question chillcd more speech than necessary and essentially reduced the First Amendment to an empty label when applied to professors.

Had the court applied the correct analysis, it would have held that the professors did indeed possess academic freedom in this case. In deciding whether the expression was so incompatible with the state's goals as to justify regulation, the court should have considered the context of the expression, the role of the professor, and the goals of the state. ${ }^{217}$ Although

212. Id. at 407.

213. Id. at 409.

214. See discussion supra Part II.A.3.

215. See Rankin v. McPherson, 483 U.S. 378, 383 (1987) ("It is clearly established that a State may not discharge an employee on a basis that infringes that employee's constitutionally protected interest in freedom of speech."); Connick v. Myers, 461 U.S. 138, 140 (1983) (“[A] public employee does not relinquish First Amendment rights to comment on matters of publie interest by virtue of government employment.”); Tinker v. Des Moines Indep. Cmty. Sch. Dist., 393 U.S. 503, 506 (1969) (noting that teachers do not "shed their constitutional rights to freedom of speech or expression at the schoolhouse gate"). Even the Urofsky court latcr noted that "it is now beyond question that a public employer does not enjoy earte blanche to sanction employees for the exercise of First Amendment rights." Urofsky, 216 F.3d at 414. It is a mystcry, then, why the Urofsky court specifically granted just such earte blanche.

216. Urofsky, 216 F.3d at 411 n.12.

217. It is important to remember that in some academic freedom cases; the state is acting against the professor, and in others, the university is acting against the professor. Where the state qua state is the regulator, the court should examine the state's goals behind the regulation; where the state institution of the university is the regulator, the court should examine the university's goals. In Urofsky, it is appropriate to investigate the state's goals (through either legislative intent or stated justification in the litigation) behind regulating professors through the statute. 
the Fourth Circuit never mentioned the state's goals in enacting the law in question, the district court stated that the goals were to avoid workplace disruption and hostile workplace claims and to ensure employee efficiency. ${ }^{218}$ However, restricting the professors' expression was not necessary to achieve these goals. The Urofsky professors' expression took place in the context of research and scholarship in their fields. ${ }^{219}$ The record demonstrated no significant workplace disruption, no inefficiency, and no hostile workplace claims with regard to such research. ${ }^{220}$ The professors' activities simply were not incompatible with the state's goals. As the district court noted: "Although workplace efficiency and the avoidance of hostile work environment claims are undoubtedly important governmental interests, the Act fails to advance these interests in a direct and material way. Moreover, the Act restricts speech far beyond what is necessary to advance the interests it purports to address." 221 In other words, restricting the professors' speech in this case was not functionally necessary to accomplishing the state's goals of workplace efficiency and the avoidance of hostile workplace claims. The district court suspected that "the Act was intended to discourage diseourse on sexual topics, 'not because it hampers public functions but simply because [the state] disagree[s] with the content of employees' speech."'222 The Fourth Circuit's opinion disregarded this salient point and failed to recognize that restricting the professors' speech

218. Urofsky v. Allen, 995 F. Supp. 634, 640 (E.D. Va. 1998).

219. Id. at 635 (noting that the professors wished to use the Internet to research indecency law, sexually explicit Victorian poetry, gender roles, human sexuality, lesbian and gay studies, and psychological research on human sexual experience); see also Urofsky, 216 F.3d at 410 n.9.

220. The district court noted that although a website maintained by one of the plaintiffs and designed as "part of a discussion about censorship, pornography and capitalist control of the Internet" drew a couple of complaints, its existenee would not be sufficicnt to support a hostile workplace claim. Urofsky, 995 F. Supp. at 639,641 n.6. Additionally, the district court noted that the harms asserted by the government must be "real, not merely conjectural," which was not the case in Urofsky. Id. at 638-39 (quoting United States v. Nat'l Treasury Employces Union, 513 U.S. 454, 474-75 (1995)). In fact, in National Treasury Employees Union, the Court emphasized that the government's burden is more stringent in cases of statutory chilling of public employee speech. National Treasury Employees Union involved a statutory speech ban, and the Court stated:

Unlike Pickering and its progeny, this case does not involve a post hoc analysis of one employee's speeeh and its impact on that employee's public responsibilities. Rather, the Government asks us to apply Pickering to Congress's wholesale deterrent to a broad category of expression by a massive number of potential speakers.

Id. at 467 . The government's burden was higher because the statutory ban "deters an enormous quantity of speeeh before it is uttered, based only on speeulation that the spcech might threaten governmental interests." Id. at 467 n.11. Because Urofsky similarly involved a statutory speech ban applied to all public employees in Virginia, the government's showing of harm should have been subjected to even higher scrutiny.

221. Urofsky, $995 \mathrm{~F}$. Supp. at 643.

222. Id. (quoting Rankin v. McPherson, 483 U.S. 378, 384 (1987)). It is important to remember that if restricting this speech had been indeed necessary to maintain workplace efficiency or to avoid hostile work environment claims (because the speech was basically ineompatible with those goals), then the state could restrict the speech, and the state's managerial interests would trump the professors' interests. In such a situation, the professors' academic freedom claim would not prevail. 
was not functionally necessary to the state's accomplishment of its efficiency and nonhostile workplace goals.

The Fourth Circuit did recognize that without academic freedom, "advances in learning surely would be hindered in a manner harmful to the university as an institution and to society at large" 223 and that "the claim of an academic institution to status as a 'university' may fairly be said to depend upon the extent to which its faculty 'members are allowed to pursue knowledge free of external constraints." ${ }^{224}$ However, the court insisted that this "academic freedom" is merely one of professional practice and that the "wisdom of a given practice as a matter of policy does not give the practice constitutional status."225 This conclusion is inconsistent with the Supreme Court's public employee precedent. Although it is true that the court need not constitutionalize professional norms of academic ethics, its characterization of university goals has meaning beyond such norms. If the public university was set up to expand knowledge and promote "advances in learning" (as the court recognized), and if a regulation hinders this goal (as the court recoguized), then that regulation is far from functionally necessary under the Supreme Court's public employee precedent. Rather, academic freedom is necessary to accomplish the goal of advancing learning, and the "policy" supporting the professional view of the freedom overlaps with the constitutional analysis.

\section{B. The Urofsky Court's Distinction Between Institutional and Individual Academic Freedom}

The Urofsky court also unnecessarily distinguished between the institutional and individual rights of academic freedom, and categorically denied the existence of the individual right. ${ }^{226}$ As discussed earlier, ${ }^{227}$ courts and commentators often divide academic freedom into two distinct rights: the right held by the professor (individual academic freedom) and the right held by the university (institutional academic freedom). Universities have asserted institutional academic freedom against First Amendment claims made by professors, students, or the state. ${ }^{228}$ This freedom derives from the idea that the university needs autonomy to achieve its unique goals. ${ }^{229}$ Significant scholarly debate has focused on whether academic

\footnotetext{
223. Urofsky, 216 F.3d at 411 n.12.

224. Id.

225. Id.

226. Id. at 412 .

227. See discussion supra Part I.C.
}

228. See Rabban, supra note 10 , at 256 ("[U]niversities have relicd on an institutional right of academic freedom to defend themselves both against the state and against students, professors, and members of the general public.").

229. See Byrne, supra note 38, at 323 ("Academic abstention has long specifically preserved university freedom from state regulation. It describes the traditional refusal of courts to extend common law rules of liability to colleges where doing so would interfere with the college administration's good 
freedom should be a right belonging to the university or to the individual professor. ${ }^{230}$ At first glance, such a distinction seems natural because the university and the professor may each assert a right against the other. ${ }^{2.31}$ However, the functional necessity approach that I advocate here obviates the need to distinguish between institutional and individual rights in certain situations. Although the Urofsky court separated the two and insisted that only institutional rights deserve protection, such separation was nonsensical under the facts of the case.

First, the Urofsky court interpreted all of the Supreme Court's academic freedom cases as protecting only the university. ${ }^{232}$ This interpretation is incorrect. In its academic freedom cases, the Court has focused on both the institution's and the individual's need for academic freedom. ${ }^{233}$ The nature of this particular institution is such that the one type of freedom is often impossible without the other. A professor's freedom means little if her university is shackled by the whim of the state, and a university's freedom means little if its professors are pawns of the state. ${ }^{234}$

In some situations, distinguishing between individual and institutional academic freedom might be helpful, ${ }^{235}$ but Urofsky is not one of these situations. As I have argued, constitutional academic freedom is a special

faith performance of its core functions."); see also id. at 327 ("Institutional academic freedom can be viewed as academic abstention raised to constitutional status, so that judges can consider whether statutes or regulations fail to give sufficient consideration to the special needs or prerogatives of the academic community."); $i d$. at 326 (pointing out that Supreme Court "counsels courts that universities proceed on assumptions differcnt from society as a whole and that an insistencc by courts on conforming to legal standards or procedures will likely destroy something uniquely valuable in higher education").

230. See discussion supra Part I.C.

231. As Byme has queried: "How can the same right protect both traditional antagonists-the professor and the university?" Byrne, supra note 38 , at 257.

232. Urofsky v. Gilmore, 216 F.3d 401, 412-15 (2000).

233. See discussion supra Part 1.B. For example, although the Sweezy Court discussed the freedom of the university, it also discussed the need to allow teachers to "remain free to inquire, to study and to evaluate, to gain new maturity and understanding," Sweezy v. New Hampshire, 354 U.S. 234, 250 (1957), and indicated that the action of the state "unquestionably" infringed Sweezy's "liberties in the areas of academic freedom." Id. As Metzger points out, the Sweezy Court expressed "confidence ... that institutional autonomy and individual freedom went automatically hand in hand." Metzger, supra note 7, at 1313. The later cases' emphasis on the institution's right to academic freedom does not necessarily represent a repudiation of earlier emphases on individual freedom.

234. See Univ. of Wis. v. Southworth, 529 U.S. 217, 237 (2000) ("Academic freedom thrives not only on the independent and uninhibited exchange of ideas among teachers and students, but also, and somewhat inconsistently, on autonomous decision making by the academy itself.") (quoting Univ. of Mich. v. Ewing, 474 U.S. 214, 226 n.12 (1985)); see also Rabban, supra note 10, at 230 ("In order to engage in critical inquiry, professors need some degree of independence from their university employers, and universities need some degrce of independence from the state.").

235. It is beyond the scope of this Comment to survey and analyze the diffcrent permutations of institutional academic freedom. For example, distinguishing between individual and institutional academic freedom may or may not be helpful in a complicatcd situation in which a professor's interests conflict with those of the peer review board or university, which in turn conflict with the state's interests. 1 argue only that in some common instances the distinction is unhelpful and unneccssary. 
instance of First Amendment application in the context of a unique institution: the university. The functional necessity calculation should not hinge on who is asserting the right; the right is academic freedom, and the right holder is either the professor or the university. The court nceded only to engage in the functional necessity equation, taking into consideration the unique role of the professor and the state's goals, to determine whether the professors' speech was properly regulated. Urofsky was an easy case, in which only one party appealed to the right of academic freedom, eliminating the possibility of conflict between different academic freedom right holders. In a casc like this, cither the professor's claim will prcvail, thus vindicating her right of academic freedom, or the state's claim will prevail, and no right of academic freedom will be vindicated. The nature of the right itself does not change or categorically disappear simply because an individual is asserting it; the claim is either vindicated or it is not.

Even in harder cases, when the professor asserts a right of academic freedom and the university also asserts the right in response, distinguishing between institutional and individual academic freedom may be unnccessary. For example, if a univcrsity promulgates a regulation prohibiting professorial expression on certain viewpoints, both types of academic frcedom rights might be asserted. The professor could claim that the regulation violates his First Amendment rights in the context of academic speech, and the university could claim that any judicial encroachment into this regulation will violate its institutional autonomy. However, the functional necessity test allows the court to plug both sets of interests into the equation. As a result, either the institution or the individual will prevail. If the university regulation is necessary to accomplish a legitimate ${ }^{236}$ educational goal, then the university's claim will prevail. But if the university regulation is not functionally necessary, the professor's claim will prevail. Because the court gauges necessity by whether the professor's speech is basically incompatible with the university's goal, if the two interests are truly incompatible, the university's managerial interest trumps the professor's expressive interest. But the functional necessity analysis requires no identification of whether the academic freedom claim is of an individual or institutional nature. Rather, the context and interests plugged into the functional nccessity test vary with the party asserting the right. The analysis in this

236. Here, "legitimate" is used in the traditional sense and means that the goal is one that the court is convinced is properly edueational and that does not violate other laws. For example, in University of California v. Bakke, 438 U.S. 265, 314 (1978), a plurality of the Supreme Court deemed the university's quota goals illegitimate because they conflicted with the Fourteenth Amendment's equal protection clause. This conclusion eliminated the university's academic freedom claim. And in University of Pennsylvania v. EEOC, 493 U.S. 182, 201 (1990), the Court held that the state could limit the university's autonomy when it conflicted with the "enforeement of civil or criminal statutes of general applicability." Finally, in Knight v. Alabama, 14 F.3d 1534, 1552 (11 th Cir. 1994), the Eleventh Circuit held that when a university's eurriculum design violates a constitutional or statutory provision, the university is not insulated by academic freedom. 
type of case simply illustrates the classic difference between a right and a right holder.

In addition to making an unnecessary distinction between two types of academic freedom, the Urofsky court was mistaken in its rationale for categorically denying individual academic freedom to professors. This mistaken rationale has two aspects. First, it seems that the court was worried about how universities and the state could properly manage professors' speech in the face of such a right. ${ }^{237}$ This worry echoes Byrne's argument that because universities necessarily engage in viewpoint discrimination in reviewing academic decisions, a court would be faced with two equally unattractive options if it concluded that a professor held any right of academic freedom: either side with the view it endorses or allow all possible viewpoints in academic arenas. ${ }^{238}$ Byrne eschews normal First Amendment tests because they "miss[] a crucial attribute of academic life: Scholars routinely are criticized for the content of their speech by other scholars, and some are eventually penalized by their institutions."239 Therefore,

[e]mploying a legal test that presumes the faculty member's speech is immune from these judgments and penalties wholly misconceives the scholarly enterprise. It is of the essence that worthy ideas be distinguished from dull, and an unobjeetionable corollary is that some speakers will be valued more highly and given more prominent positions. ${ }^{240}$

Byrne concludes that any test other than a type of good faith or rational basis one would "deny ... [the] collective authority" of university officials and thereby "deny the structural principle of collective scholarship upon which the university is built." ${ }^{241}$ For these reasons, like the Urofsky court, Byme believes that constitutionalized academic freedom has true meaning only with regard to the institution. ${ }^{242}$

However, Byrne is incorrect in concluding that the only way for courts to accommodate the necessary viewpoint discrimination and

237. See Urofsky, 216 F.3d at 409-10. The court first noted the managerial needs of the university and then characterized the professors' claim as follows: "Appellees contend that a university professor possesses a constitutional right to determine for himself, without the input of the university (and perhaps even contrary to the university's desires), the subjects of his research, writing, and teaching." Id. The court also quoted Justice Black's concurrence in Epperson v. Arkansas, 393 U.S. 97, 113-14 (1968), in which he stated that he was "not ready to hold that a person hired to teach school children takes with him into the classroom a constitutional right to teach soeiological, economic, political, or religious subjects that the school's managers do not want discussed." Urofsky, 216 F.3d at 415 n. 15.

238. Byrne, supra note 38 , at 305-06.

239. Id. at 310 .

240. Id. See also Mark G. Yudof, Three Faces of Academic Freedom, 32 LoY. L. REv. 831, 837. 42 (1987), who notes that one reason he is troubled by thinking of academic freedom as a First Amendment right held by professors is that it may not leave room for necessary university management.

241. Byrne, supra note 38 , at 310 .

242. Id. at 255 . 
"structural principle of collective scholarship" is to deny professors any assertion of constitutionalized academic freedom. ${ }^{243}$ As I have argued, the functional necessity test explicitly accommodates such institutional structures by focusing courts on the question of whether regulating the speech is necessary to the functioning of those structures. The functional necessity test itself is specifically motivated by the managerial concerns voiced by Byrne and the Urofsky court. It is important to remember that the reason that the First Amendment is applied differently to public employee speech than in situations in which the state governs citizen speech is that the state needs a freer hand in regulating its employees within the managerial realm. ${ }^{244}$ Therefore, blanket denial of individual public employee freedom is not even necessary to account for Byrne's concerns. ${ }^{245}$ In fact, such blanket denial has been forbidden by the Supreme Court. ${ }^{246}$

Second, the Urofsky court was concerned that recognizing an individual right to academic freedom would "raise the specter of a constitutional right enjoyed by only a limited class of citizens." 247 However, as discussed earlier, analyzing academic freedom within the public employee framework does not create special rights for professors ${ }^{248}$ Rather, such analysis merely applies the First Amendment functionally in the context of a governmental institution. The analysis investigates the unique nature of the university as a different type of state institution, the unique nature of professors as different types of state employees, and the conditions necessary for the accomplishment of several unique educational goals. Academic freedom is a label for the conditions necessary to accomplish certain educational goals. It is not a greater or different right, but the result of a reformulated public employee test as applied to this different type of institution. The result just happens to be that professors will need to exercise First Amendment rights more often than other types of public employees. In other words, the court is incorrect in stating that under existing doctrine, all public employees receive the "same protection."249 One need only examine

243. See id.

244. See discussion supra Part II.A.I

245. Byrne's test thus loses its utility, and if the goal is to increase the total amount of allowed speech, his test should not be favored over the functional necessity test. See discussion supra Part II.B.4 (arguing that functional necessity test protects more speech than rational basis test, reasonable relationship test, and traditional public forum doctrine).

246. See, e.g., Connick v. Myers, 46 I U.S. I38, I40 (1983).

247. Urofsky v. Gilmore, 216 F.3d 40I, $4 \mathrm{I} 2$ n.13 (4th Cir. 2000).

248. See discussion supra Part II.B.4.

249. Urofsky, 216 F.3d at 414. The court also stated that the Pickering line of case law has "subsumed" the older academic freedom cases discussing individual academic freedom. $I d$. The error of this view is confirmed by a quick glance at a post-Pickering case, University of Michigan v. Ewing, 474 U.S. 2I4, 226 n. I2 (I985), in which the Court stated: "Academic freedom thrives not only on the independent and uninhibited exchange of ideas among teachers and students, but also, and somewhat inconsistently, on autonomous decisionmaking by the academy itself." 
Rankin v. McPherson ${ }^{250}$ or Brown v. Gilnes ${ }^{251}$ in order to realize that the protection will vary depending on the nature of the job and the type of institution. As mentioned earlier, the Fourth Circuit itself has elsewhere recognized this point. ${ }^{252}$

The Urofsky court started out on the right foot by recognizing that the professors' expression took place within the state's managerial realm, but the court made a misstep at every turn thereafter. The court was mistaken in automatically deferring to the state, in failing to ask the operative question of functional necessity, and in categorically denying the existence of an individual right to constitutional academic freedom.

\section{CONCLUSION}

Although the Supreme Court has not created an explicit academic freedom standard, it has given lower courts all of the tools they need to analyze these important cases in a way that is logically sound and workable. Pickering set forth the line between speech made in the role of citizen and speech made in the role of public employee. When the speech is made in a public university professor's role as a citizen, normal heightened scrutiny First Amendment rules will apply. Such cases are not properly labeled academic freedom cases. However, much academic speech is made in the professor's role as a public employee. In these cases, the state has a managerial interest in the speech, and analysis must proceed under a different framework.

At this point, the court should conduct an instrumental calculation of whether restricting the speech is functionally necessary to realization of the state or institutional goals. To answer this question, the court should perform a case-by-case analysis of the context of the speech and the role of the professor in connection with the state's or institution's educational goals. In many situations, a professor's speech will not be incompatible with these objectives. Rather, academic freedom will be necessary to accomplish two generally categorized missions: critical democratic education and the promotion of new discoveries and knowledge. The functional necessity approach renders it unhelpful to distinguish between the rights of individual and institutional academic freedom in certain common cases, protects more speech than alternative methods do, and furthers the constitutional values behind the Supreme Court's academic freedom and public employee jurisprudence.

252. See Jurgensen v. Fairfax County, 745 F.2d 868, 880 (4th Cir. 1984) ("[C]ourts must give weight to the nature of the employee's job in assessing the possible effect of his action on employee morale, discipline or efficiency... State inhibition of acadcmic freedom is strongly disfavored. In polar contrast is the discipline demanded of, and freedom correspondingly denied to[,] policemen."). 
The Supreme Court holds academic freedom in such high esteem as to assert that "our civilization will stagnate and die" without it. ${ }^{253}$ This apocalyptic view may seem to be exaggerated, but it is at least clear that constitutional academic freedom for professors is important and cannot be dismissed out of hand in the manner undertaken by the Urofsky court. Although public university professors will not reside in the exalted position of being priests of democracy in every situation, I have endeavored to show that courts already are well equipped to protect these professors from becoming perpetual pawns of the state. 